\title{
Purification of a Multipotent Antideath Activity from Bovine Liver and Its Identification as Arginase: Nitric Oxide-Independent Inhibition of Neuronal Apoptosis
}

\author{
Fred Esch, ${ }^{1}$ Kuo-I Lin, ${ }^{4}$ Anna Hills, ${ }^{1}$ Khalequz Zaman, ${ }^{4}$ Jay M. Baraban, ${ }^{3}$ Sukalyan Chatterjee, ${ }^{4}$ Lee Rubin, ${ }^{1}$ \\ David E. Ash, ${ }^{2}$ and Rajiv R. Ratan ${ }^{4,5}$ \\ ${ }^{1}$ Eisai London Research Laboratories, London, England, 2Department of Biochemistry, Temple University School of \\ Medicine, Philadelphia, Pennsylvania, ${ }^{3}$ Department of Neuroscience, The Johns Hopkins University School of Medicine, \\ Baltimore, Maryland, and ${ }^{4}$ Department of Neurology and ${ }^{5}$ Program in Neuroscience, Harvard Medical School and The \\ Beth Israel-Deaconess Medical Center, Boston, Massachusetts
}

\begin{abstract}
Catalase is an antioxidant enzyme that has been shown to inhibit apoptotic or necrotic neuronal death induced by hydrogen peroxide. We report the purification of a contaminating antiapoptotic activity from a commercial bovine liver catalase preparation by following its ability to inhibit apoptosis when applied extracellularly in multiple death paradigms. The antiapoptotic activity was identified by protein microsequencing as arginase, a urea cycle and nitric oxide synthase-regulating enzyme, and confirmed by demonstrating the presence of antiapoptotic activity in a $>97 \%$ pure preparation of recombinant arginase. The pluripotency of recombinant arginase was demonstrated by its ability to inhibit apoptosis in multiple paradigms including rat cortical neurons induced to die by glutathione depletion and oxidative stress, by $100 \mathrm{~nm}$ staurosporine treatment, or by Sindbis virus infection. The protective effects of
\end{abstract}

arginase in these apoptotic paradigms, in contrast to previous studies on excitotoxic neuronal necrosis, are independent of nitric oxide synthase inhibition. Rather, arginase-induced depletion of arginine leads to inhibition of protein synthesis, resulting in cell survival. Because inhibitors of nitric oxide synthesis and of protein synthesis have been shown to decrease necrotic and apoptotic death, respectively, in animal models of stroke and spinal cord injury, arginine-depleting enzymes, capable of simultaneously inhibiting protein synthesis and nitric oxide generation, may be propitious therapeutic agents for acute neurological diseases. Furthermore, our results suggest caution in attributing the cytoprotective effects of some catalase preparations to catalase.

Key words: apoptosis; glutathione; neurons; oxidative stress; arginase; nitric oxide; staurosporine
Apoptosis is a morphologically distinct type of cell death characterized by nuclear and cytoplasmic condensation, clumping of nuclear chromatin, and membrane blebbing (Wyllie et al., 1980). The transduction of apoptosis in neurons often requires new protein synthesis (Martin et al., 1988; Pittman et al., 1993; Ratan et al., 1994a,b; Serghini et al., 1994; Dreyer et al., 1995; Koh et al., 1995) and involves both positive and negative regulators such as the Bcl-2/Bax family of proteins (Garcia et al., 1992; Levine et al., 1993; Mah et al., 1993; Miller et al., 1997; Oh et al., 1997), the retinoblastoma (Clarke et al., 1992; Jacks et al., 1992; Lee et al., 1992) and p53 gene products (Wood and Youle, 1995), and others (Freeman et al., 1994). Interleukin 1- $\beta$ converting enzyme-like cysteine proteases, known as caspases, seem to form part of a common final effector pathway leading to degradation of repair proteins (Casciola-Rosen et al., 1996) and, ultimately, to controlled destruction of the cell (Gagliardini et al., 1994; Nicholson and Thornberry, 1997).

Although classically associated with physiological processes such as nervous system development (Johnson et al., 1980; Op-

\footnotetext{
Received Dec. 15, 1997; revised Feb. 20, 1998; accepted March 13, 1998.

This work was supported by the National Institutes of Health Grant DK44841 to D.E.A. and by the Eisai Company of Japan (F.E., A.H., and L.R.). We would like to thank Carol Doherty, Rick Huganir, and Bill Bishai for assistance and helpful discussions.

Correspondence should be addressed to Dr. Rajiv R. Ratan, Neurology Laboratories at The Beth Israel-Deaconess Medical Center, Harvard Institutes of Medicine, Room 857, 77 Avenue Louis Pasteur, Boston, MA 02115.

Copyright (C) 1998 Society for Neuroscience $\quad 0270-6474 / 98 / 184083-13 \$ 05.00 / 0$
}

penheim, 1991; Clarke, 1994), apoptosis can be induced in neurons in vitro by many pathological stimuli including oxidative stress (Ratan et al., 1994a,b; Rothstein et al., 1994; Troy and Shelanski, 1994; Bonfoco et al., 1995), viral infection (Levine et al., 1993), mitochondrial toxins (Behrens et al., 1995), and $\beta$-amyloid (Loo et al., 1993). These observations correlate well with recent evidence demonstrating that apoptosis is a mechanism of neuronal loss in a variety of neurodegenerative states including stroke (Linnik et al., 1993; Gwag et al., 1995; Li et al., 1995; Du et al., 1996a), spinal cord injury (Crowe et al., 1997; Liu et al., 1997), Alzheimer's disease (Cotman and Anderson, 1995), amyotrophic lateral sclerosis (Mu et al., 1996), and Huntington's disease (Portera-Calliau et al., 1995). However, the precise signals that activate apoptosis in these pathological conditions remain unclear.

Among the candidate second messenger molecules that may activate pathological neuronal apoptosis, reactive oxygen species such as hydrogen peroxide have been hypothesized to play an important role (Bredesen, 1995). Indeed, addition of peroxide to neurons can lead to apoptosis (Whittemore et al., 1994; Satoh et al., 1996; Tong and Perez-Polo, 1996; Hoyt et al., 1997), and peroxide has been implicated as a mediator of $\beta$-amyloid apoptosis (Loo et al., 1993; Behl et al., 1994). Additionally, sympathetic neurons induced to undergo apoptosis by removal of nerve growth factor experience a transient increase in reactive oxygen species as measured by the free radical reporter 6-carboxy-2',7'dichlorofluorescein diacetate (Greenlund et al., 1995; Bae et al., 
1997); drugs such as $N$-acetylcysteine with peroxide-scavenging ability (Aruoma et al., 1989) can inhibit apoptosis of growth factor-deprived sympathetic neurons (Ferrari et al., 1995). Finally, peroxide can activate apoptosis-related transcription factors such as activator protein-1 (Estus et al., 1994; Ham et al., 1995) and NF- $\kappa$ B (Lin et al., 1995; Clemens et al., 1997) in neuron-like pheochromocytoma PC12 cells (Tong and PerezPolo, 1996), suggesting that peroxide may act as a trigger for the expression of "death" gene products in response to some neuronal apoptotic stimuli.

To examine further the role of hydrogen peroxide in activating neuronal apoptosis, we added the enzymatic peroxide scavenger catalase to the extracellular bathing medium of neurons induced to die apoptotically by depletion of the antioxidant glutathione (Ratan et al., 1994a), by exposure to low doses of the protein kinase inhibitor staurosporine (Koh et al., 1995; Prehn et al., 1997), or by infection with the alphavirus Sindbis virus (Levine et al., 1993). Because peroxide is a noncharged species capable of diff using through lipid membranes, we reasoned that extracellular catalase should reduce intracellular peroxide by decreasing extracellular peroxide concentrations and thereby drawing peroxide out of the cell. Here, we report that a crude commercial bovine liver "catalase" preparation added to the extracellular medium is able to block neuronal apoptosis in multiple death paradigms. However, we demonstrate that an antiapoptotic activity inherent in this extract is not catalase but rather a contaminant that we identified as the urea cycle and nitric oxide synthase-regulating enzyme arginase (Jenkinson et al., 1996; Morris, 1998). Moreover, we demonstrate that the protective effects of arginase cannot be attributed to nitric oxide synthase inhibition but rather result from arginine depletion and inhibition of protein synthesis. These observations define a novel pathway by which arginine participates in neuronal cell death and identify amino aciddegrading enzymes such as arginase as a new class of neuronal antiapoptotic agents.

\section{MATERIALS AND METHODS}

Primary neurons. Cell cultures were obtained from the cerebral cortex of fetal Sprague Dawley rats (day 17 of gestation) as described previously (Murphy et al., 1990). All experiments were initiated 24-72 hr after plating. These young cultures do not express significant receptormediated responses to glutamate and thus do not seem to be susceptible to excitotoxicity. For cytotoxicity studies, the cells were rinsed once with warm PBS and then changed to medium [Minimum Essential Medium (MEM; Gibco BRL) with $5.5 \mathrm{gm} / 1$ glucose, $10 \%$ FCS, 2 mM L-glutamine, and $100 \mu \mathrm{M}$ cystine] containing the glutamate analog homocysteate (HCA; $1 \mathrm{mM}$ ), the protein kinase inhibitor staurosporine (STS; $100 \mathrm{nM}$ ), or Sindbis virus (SV; strain AR339) added at a multiplicity of infection (MOI) of 1-5 plaque-forming units (PFU) per cell. Homocysteate was diluted from 100 -fold concentrated solutions that were adjusted to $\mathrm{pH}$ 7.5. Media containing staurosporine were made by diluting at least 1000-fold concentrated solutions prepared in dimethylsulfoxide (DMSO vehicle, $0.1 \% \mathrm{v} / \mathrm{v}$, had no protective effect alone). Viability was assessed by phase contrast microscopy, by lactate dehydrogenase (LDH) release (Ratan et al., 1994a,b), or by using calcein AM/ethidium homodimer-1 staining (Molecular Probes, Eugene, OR) and fluorescence microscopy. To evaluate the effects of extracellular catalase on cytotoxicity, we added bovine liver catalase (2100 units/ml; \#C6665; Sigma, St. Louis, MO) at the time cortical neurons were exposed to HCA, STS, or SV, and viability was assessed as described above at 24,60 , or $48 \mathrm{hr}$, respectively. In parallel, purer preparations of catalase from bovine liver (1-30,000 units/ml), Aspergillus niger (1-30,000 units/ml), or human erythrocyte (1-30,000 units/ml), all from Calbiochem (La Jolla, CA), recombinant arginase $\left(100-8000 \mathrm{ng} /\right.$ well) (Cavalli et al., 1994), or $N^{\mathrm{G}}$-nitro-Larginine methyl ester hydrochloride (L-NAME; $100 \mu \mathrm{M}-1 \mathrm{mM}$; Calbiochem) were tested against HCA-, STS-, or SV-induced cytotoxicity.

Mouse N18 neuroblastoma cells. Cells were grown as described (Levine et al., 1993) in MEM media containing 10\% FCS, 2 mM L-glutamine, penicillin $(50$ units $/ \mathrm{ml})$, and streptomycin $(50 \mu \mathrm{g} / \mathrm{ml})$. Cells were trypsinized, plated in 24 well dishes at a density of $80,000 \mathrm{cells} / \mathrm{ml}$ and in 96 well dishes at a density of 5000 cells per well, and allowed to adhere overnight for bioassays. After addition of fresh media, cells were preincubated for $2 \mathrm{hr}$ with crude bovine liver catalase (Sigma), purer preparations of catalase (Calbiochem), $N^{\mathrm{G}}$-methyl-L-arginine (L-NMA; 100 $\mu \mathrm{M}$; Calbiochem), guanidinoethyldisulfide (GED; $100 \mu \mathrm{M}$; Calbiochem), arginine decarboxylase $(0-4000 \mu \mathrm{g} / \mathrm{ml} ; \quad$ Sigma $)$, asparaginasepolyethylene glycol (1-5 units/ml; Sigma), catalase-polyethylene glycol (1-3000 units/ml; Sigma), superoxide dismutase-polyethylene glycol (13000 units/ml; Sigma), or the antiapoptotic activity (AAA) at various stages of purification and then exposed to SV at a MOI of 1-5. Antiapoptotic activity was defined by suppression of nuclear morphological changes characteristic of apoptosis (Ratan et al., 1994a) as monitored by Hoechst 33452 staining and fluorescence microscopy and quantitated by a viability index. The viability index was defined as the ratio of LDH activities (Cytotox LDH assay kit; Promega, Madison, WI) in the cell lysates of cells exposed to both the AAA and virus versus that in cell lysates of cells exposed to AAA alone. One unit of AAA was established as the amount of protein per well giving rise to $50 \%$ viability according to the index defined above.

Inactivation of catalase in the bovine liver catalase preparation. The catalase activity in crude bovine liver catalase was inactivated by exposure to $40 \mathrm{~mm}$ 3-amino-1,2,4-triazole or $0.5 \mathrm{~mm}$ phenylhydrazine (Ortiz de Montellano and Kerr, 1983; Kingma et al., 1996) as described in Inactivation of catalase activity was verified with a Clark oxygen electrode (Yellow Springs Instruments, Yellow Springs, OH) (Rorth and Jensen, 1967) fitted to a $1.5 \mathrm{ml}$ glass cell (Gilson Medical Electric, Middleton, WI) and was standardized against a solution of pure bovine liver catalase (Calbiochem). Similar catalase activity results were obtained using a spectrophotometric assay based on the disappearance of exogenously added peroxide (Brannan et al., 1981).

Replication in vitro. N18 cells were grown to near confluence in 12 well plates and were infected as described above. Supernatant fluid was removed from three wells at $48 \mathrm{hr}$ after infection plus or minus varying concentrations of crude bovine liver catalase, virus from each well was quantitated by plaque formation in baby hamster kidney-21 cells (PFU/ $\mathrm{ml}$ ), and the geometric mean was determined for each time point.

Purification of AAA from commercial bovine liver catalase. Preliminary purification steps were performed at $4^{\circ} \mathrm{C}$ on a Bio-Rad BioLogic FPLC system; subsequent electrophoresis steps were used to achieve final protein homogeneity. Crude bovine liver catalase (1 gm; Sigma) was dissolved in $30 \mathrm{ml}$ of $20 \mathrm{~mm}$ Tris-HCl, pH 7.5, plus $1 \mathrm{M} \mathrm{NaCl}$ and chromatographed at $5 \mathrm{ml} / \mathrm{min}$ on a Pharmacia chelating Sepharose column $\left(2.5 \times 5 \mathrm{~cm}\right.$; charged with $\mathrm{ZnSO}_{4}$ according to the manufacturer's recommendations) equilibrated in the same buffer; the AAA was not retained. After equilibration with $50 \mathrm{~mm}$ sodium borate at $\mathrm{pH}$ 9.5 (Buffer A) by dialysis at $4^{\circ} \mathrm{C}$, the "Zn-AAA" was loaded onto a Bio-Rad Bioscale Q20 anion exchange column and washed with $35 \mathrm{ml}$ of Buffer A at $5 \mathrm{ml} / \mathrm{min}$. "Q20-AAA" eluted as a sharp peak during the initial phase of a $200 \mathrm{ml} 0-50 \%$ linear gradient using $50 \mathrm{~mm}$ sodium borate, $\mathrm{pH} 9.5$, plus $1 \mathrm{M} \mathrm{NaCl}$ as Buffer B. Bioactive fractions were pooled and concentrated using CentriPrep-30 filtration units (Amicon, Beverly, MA) to $\leq 5 \mathrm{ml}$ and were applied to a Superdex $200 \mathrm{HR}(26 / 60)$ size exclusion column (Pharmacia, Piscataway, NJ) equilibrated in Dulbecco's PBS. "S200-AAA" was eluted at $3 \mathrm{ml} / \mathrm{min}$ with an apparent molecular weight of $\sim 69 \mathrm{kDa}$. The bioactive fractions were pooled, concentrated via CentriPrep-30 filtration units, and filter sterilized.

S200-AAA $(6.8 \mathrm{mg})$ was equilibrated at room temperature in $8 \mathrm{M}$ urea, $0.5 \%$ Triton $\mathrm{X}-100$, and $2 \mathrm{~mm}$ Tris by dialysis overnight and then was concentrated via MicroCon-30 filtration to $\sim 0.1 \mathrm{ml} ; 5.4 \mathrm{mg}$ of the concentrated S200-AAA was loaded onto a 2-cm-wide lane of a $0.5-\mathrm{mm}$ thick Immobiline $\mathrm{pH}$ 5.6-6.6 isoelectric focusing gel (IEF; Pharmacia) previously equilibrated in $2.5 \% \mathrm{pH} 3-10$ pharmalytes, $8 \mathrm{M}$ urea, $20 \mathrm{~mm}$ dithiothreitol, $2 \mathrm{~mm}$ Tris, and $0.5 \%$ Triton X-100. After $6 \mathrm{hr}$ of focusing at $3500 \mathrm{~V}$, the sample lane in the gel was cut into $0.5-\mathrm{cm}$-wide strips between the cathode and anode (22 strips across the $11-\mathrm{cm}$-wide gel). The individual gel strips were electroeluted in a Centrilutor (Amicon) electroelutor using CentriCon-30 filtration units at $200 \mathrm{~V}$ for $2 \mathrm{hr}$ at room temperature in a $1 \times$ Laemmli buffer lacking SDS $(25 \mathrm{~mm}$ Tris, $192 \mathrm{~mm}$ glycine, $\mathrm{pH}$ 8.3). The electroeluted fractions were subsequently concentrated to "dryness" in the CentriCon-30 filtration unit and redissolved in $0.1 \mathrm{ml}$ of PBS.

Twenty-five percent of each bioactive "IEF-AAA" fraction was sub- 
A

\section{$\%$ Cell Viability (Cortical Neurons)}

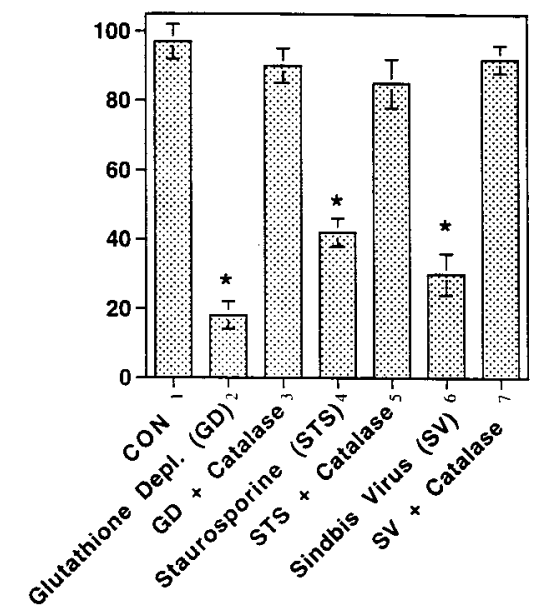

B

$\%$ Cell Viability (N18 Cells)

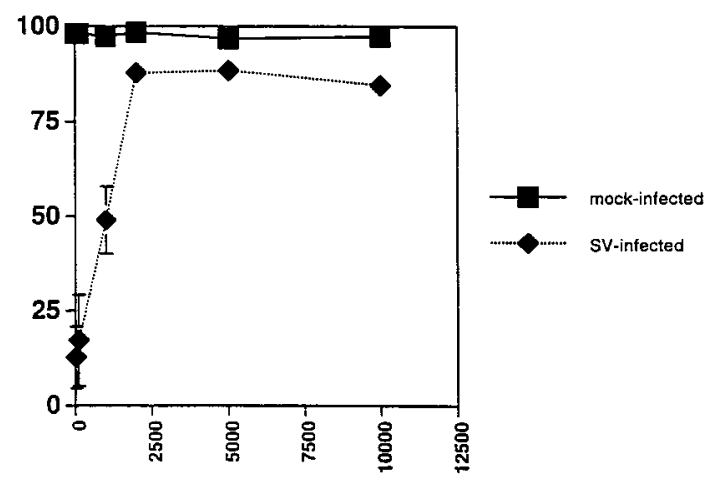

Extracellular Catalase (units/ml)

C

Sindbis Virus production $(\log 10 \mathrm{PFU} / \mathrm{ml})$

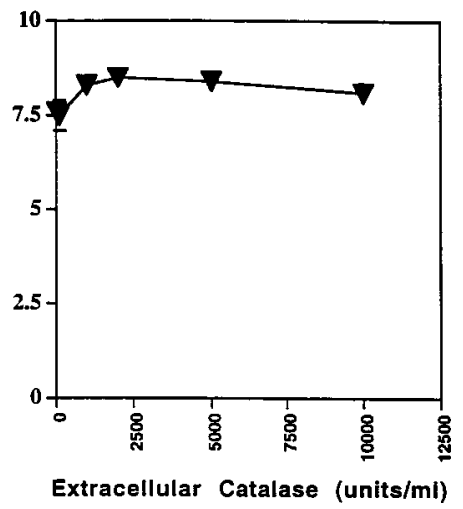

jected to $10 \%$ SDS-PAGE on a 1-mm-thick minigel and electroblotted onto polyvinylidene fluoride (PVDF; Bio-Rad transblot membrane) in $10 \mathrm{~mm}$ 3-(cyclohexylamino)-1-propanesulfonic acid, $\mathrm{pH} 11,1 \%$ methanol, and $0.01 \%$ SDS for $90 \mathrm{~min}$ at $0.75 \mathrm{~A}$. The blot was stained for $5 \mathrm{~min}$ in $0.1 \%$ amido black $/ 10 \%$ acetic acid and then destained in $\mathrm{dH}_{2} \mathrm{O}$.

Protein sequencing. The $36 \mathrm{kDa}$ protein band from the electroblotted IEF-AAA fractions was excised into $1 \times 1 \mathrm{~mm}$ PVDF squares and washed in $100 \mathrm{ml}$ of methanol to remove excess dye. For each sample, the PVDF squares were suspended in $20 \mu \mathrm{l}$ of digestion buffer $(5 \mathrm{~mm}$
Figure 1. Bovine liver catalase prevents cell death induced by glutathione depletion $(G D)$, STS treatment, or $S V$ infection. A, At $24-72 \mathrm{hr}$ after plating, cultures were exposed to $1 \mathrm{mM}$ HCA to inhibit competitively neuronal cystine transport and to induce glutathione depletion, exposed to $100 \mathrm{nM}$ staurosporine, or infected with $S V$ (MOI, 1-5). All of these treatments have been shown previously to induce morphological and biochemical features characteristic of apoptosis (Levine et al., 1993; Ratan et al., 1994a; Koh et al., 1995; Prehn et al., 1997). In parallel, exposure to each of these apoptosis inducers was conducted in the presence of 2100 units $/ \mathrm{ml}$ of bovine liver catalase. Bovine liver catalase was added at the same time that cytotoxic agents were added. The cells were harvested at $24 \mathrm{hr}(G D), 60 \mathrm{hr}(S T S)$, or $48 \mathrm{hr}(S V)$ and processed for calcein AM and ethidium homodimer-1 (live/dead) staining. Briefly, calcein AM $(2 \mu \mathrm{M})$ and ethidium homodimer $(1 \mu \mathrm{M})$ are added to the bathing medium for 30-45 min. Membrane-permeant calcein AM is cleaved by esterases in live cells to yield cytoplasmic green fluorescence, and ethidium homodimer-1 labels nucleic acids of membrane-compromised cells with red fluorescence. Fluorescence was visualized using a fluorescein long-pass filter set. Approximately 250 cells were counted in four fields per well. The ratio of live cells to live plus dead cells defines the percentage of cell viability. Data (bars) are mean \pm SEM values from three to five experiments performed in triplicate wells; ${ }^{*} p<0.05$ by ANOVA. Catalase did not enhance viability of control $(C O N)$ cultures. $B$, Concentration response of bovine liver catalase protection $48 \mathrm{hr}$ after $S V$ infection in mouse N18 neuroblastoma cells is shown. Cells were plated in $0.5 \mathrm{ml}$ of MEM medium containing either no additive or the indicated concentrations of bovine liver catalase. Viability was assessed by trypan blue exclusion (Levine et al., 1993). Similar results were obtained with the live/dead staining described in $A$. Error bars represent SEM $(n=5)$. $C$, Cumulative $S V$ production is unaltered by bovine liver catalase in N18 cells. At $48 \mathrm{hr}$ after infection, the media of infected cells ( \pm bovine liver catalase) were collected, and viral titers were measured in PFU per ml as described in Materials and Methods. Error bars represent SEM $(n=5)$.

Tris-HCl, $\mathrm{pH} 8.5,0.1$ mm EDTA, $1 \% N$-octyl- $\beta$-D-glucopyranoside, and $10 \%$ acetonitrile) and incubated at $37^{\circ} \mathrm{C}$ for $30 \mathrm{~min}$. Then $0.2 \mathrm{mg}$ of lysylendopeptidase $\mathrm{c}$ was added, and the sample was digested overnight at $37^{\circ} \mathrm{C}$. The digest was sonicated for $5 \mathrm{~min}$ and microfuged to recover soluble peptides. This process was repeated first with $20 \mu \mathrm{l}$ of digestion buffer and then with $100 \mu \mathrm{l}$ of $0.1 \%$ trifluoroacetic acid to enhance peptide fragment recoveries. The soluble peptide fractions were pooled, dried to 5-10 $\mu \mathrm{l}$ in a vacuum centrifuge, and chromatographed on a Reliasil C18 $(1 \times 150 \mathrm{~mm})$ reversed-phase column. Microsequencing of 
Table 1. Irreversible inhibition of catalase activity in the bovine liver catalase preparation does not inhibit its antiapoptotic activity

Catalase activity

Cell viability (\% of control) (\% of control)

Bovine liver catalase +

$\begin{array}{lcc}\text { no inhibitor } & 100 & 76 \pm 6 \\ \text { 1:2 dilution } & 50 & 73 \pm 12 \\ \text { 1:5 dilution } & 20 & 62 \pm 6 \\ \text { 1:10 dilution } & 10 & 6 \pm 4 \\ \text { Bovine liver catalase }+ & & \\ 40 \mathrm{~mm} \text { aminotriazole } & 1.25 \pm 1^{*} & 66 \pm 4 \\ \text { 1:2 dilution } & 0.63 & 70 \pm 9 \\ \text { 1:5 dilution } & 0.25 & 70 \pm 11 \\ \text { 1:10 dilution } & 0.13 & 13 \pm 6 \\ \text { Bovine liver catalase }+ & & 67 \pm 4 \\ 0.5 \text { mm phenylhydrazine } & 4 \pm 1.3^{*} & 68 \pm 6 \\ \text { 1:2 dilution } & 2.0 & 57 \pm 2 \\ \text { 1:5 dilution } & 0.8 & 15 \pm 4 \\ \text { 1:10 dilution } & 0.4 & \end{array}$

Bovine liver catalase $(7 \mathrm{mg} / \mathrm{ml} ; 21,000$ units $/ \mathrm{ml})$ in PBS was exposed to $1 \mathrm{~mm}$ peroxide alone (no inhibitor) or $1 \mathrm{~mm}$ peroxide in the presence of the irreversible catalase inhibitors 3-amino-1,2,4-triazole $(40 \mathrm{~mm})$ or phenylhydrazine $(0.5 \mathrm{~mm})$ for $1 \mathrm{hr}$ at $37^{\circ} \mathrm{C}$. These inhibitors require the presence of peroxide to inhibit catalase fully. After $1 \mathrm{hr}$ at $37^{\circ} \mathrm{C}$, the free inhibitors were removed by dialysis overnight at $4{ }^{\circ} \mathrm{C}$ against three changes of 100 -fold excess volume of PBS containing no inhibitors of catalase using a $10 \mathrm{kDa}$ cutoff dialysis membrane. A Clark electrode and a chromagen-based assay (see Materials and Methods) were independently used to measure catalase activity in treated and untreated extracts. Catalase activity was measured in two independent experiments and is expressed as a percentage of the catalase activity in the absence of inhibitors. The dialyzed preparation from each treatment group was sterile filtered, and $200 \mu \mathrm{l}$ of the extract was added at the time of SV or mock infection to $1 \mathrm{ml}$ of media bathing 40,000 N18 neuroblastoma cells plated in 12 well dishes. In parallel, 1:2, 1:5, and 1:10 dilutions of extracts from each treatment group were also added to SV- or mock-infected N18 cells. Forty-eight hours later, the media was collected, and the catalase activity was measured to verify that aminotriazole and phenylhydrazine are irreversible inhibitors (data not shown). Additionally, cell viability as a percentage of mock-infected control was measured in two experiments performed in duplicate for each group by measurement of cell associated LDH activity (see Materials and Methods). *indicates significant difference from corresponding control at $p<0.05$ using ANOVA and the StudentNeuman-Keuls test.

the purified peptides was performed on a Hewlett Packard G1000A protein sequencer using version 3.0 chemistry.

Preparation of recombinant arginase and arginase enzymatic assays. Recombinant rat liver arginase was expressed and purified as described previously (Cavalli et al., 1994). Arginase enzymatic activity was assessed by the isonitrosopropriophenone-based assay as described by Kuhn et al. (1995) except that the enzymatic reaction buffer contained $1 \mathrm{mg} / \mathrm{ml}$ bovine serum album and was adjusted to $\mathrm{pH} 9.5$ or 7.4 .

$\left[{ }^{35}\right.$ S $]$ cysteine and methionine incorporation studies. Radioactive labeling experiments were performed using EasyTag express protein labeling mix (New England Nuclear, Boston, MA) as described previously (Ratan et al., 1994b) with the following modifications. N18 cells were plated into 6 well dishes at a density of $5 \times 10^{4}$ cells per well. Before labeling, the media were changed and replaced with media containing arginase $(0-4000 \mathrm{ng} /$ well $)$ for $4 \mathrm{hr} ; 2 \mu \mathrm{Ci}$ of $\left[{ }^{35} \mathrm{~S}\right]$ cysteine/ methionine was then added to each well for $4 \mathrm{hr}$. The labeling was stopped by three rapid washes with $4 \mathrm{ml}$ of ice-cold PBS supplemented with $1 \mathrm{mM} \mathrm{CaCl}_{2}$. Immediately after the washes, the cells were lysed with $3 \%$ perchloric acid, scraped, and transferred to microf uge tubes. The samples were spun at $12,000 \mathrm{rpm}$ in a microf uge at $4^{\circ} \mathrm{C}$ for $20 \mathrm{~min}$, and the radioactivity of an aliquot of the supernatant was determined by liquid scintillation counting as a measure of the acid-soluble $\left[{ }^{35} \mathrm{~S}\right]$ cysteine/methionine. The acid-precipitable pellet containing the labeled, newly synthesized protein was washed and then repelleted. The supernatant was discarded, and the pellet was dissolved in $0.1 \mathrm{M}$ $\mathrm{NaOH}$. The radioactivity in this $\mathrm{NaOH}$ solute was measured, and the protein was determined by the bicinchoninic acid reagent method (Pierce, Rockford, IL). Viability assays were performed in parallel as described above.
Effects of arginase on tumor necrosis factor- $\alpha$-induced cytotoxicity of 373 cells. Immortalized mouse embryo fibroblasts were grown as described (Beg and Baltimore, 1996) at a density of 2000 cells per well in 96 well plates, allowed to adhere overnight, and treated with $10 \mathrm{ng} / \mathrm{ml}$ mouse tumor necrosis factor (TNF)- $\alpha$ (Boehringer Mannheim, Indianapolis, IN) plus or minus recombinant arginase $(100-5000 \mathrm{ng} / \mathrm{ml})$. Viability was assessed $24 \mathrm{hr}$ later using MTT or LDH assay and the viability index described above.

Statistics. Results are presented as the mean \pm SEM for three to five experiments unless otherwise noted. Experimental groups with multiple treatments were analyzed by ANOVA.

\section{RESULTS \\ Bovine liver catalase inhibits apoptosis induced by multiple stimuli}

In previous studies, we demonstrated that exposure of immature cortical neurons to glutamate or to the glutamate analog HCA results in depletion of glutathione- and oxidative stress-induced cell death with morphological and biochemical features characteristic of apoptosis (Ratan et al., 1994a,b). To determine whether peroxide mediates glutathione depletion-induced apoptosis, we examined the protective effects of extracellular catalase in this paradigm. At a concentration of 2100 units $/ \mathrm{ml}$, extracellular catalase inhibits glutathione depletion-induced death (Fig. 1A). The ability of catalase to suppress the chromatin condensation and nuclear fragmentation characteristic of apoptosis was verified by Hoechst 33258 staining and fluorescence microscopy (data not shown).

To investigate whether extracellular catalase can act as a multipotent inhibitor of neuronal apoptosis, we investigated the effects of this agent on apoptosis induced by exposure of rat cortical neurons to $100 \mathrm{~nm}$ staurosporine or apoptosis induced by Sindbis virus infection of rat cortical neurons (Lewis et al., 1996) or mouse N18 neuroblastoma cells (Levine et al., 1993). Addition of extracellular catalase to the bathing medium at the time of staurosporine treatment or SV infection inhibits cell death (Fig. $1 A, B$ ). The protective effects of catalase were seen in the absence of effects on Sindbis virus entry or replication (Fig. $1 C$ ).

\section{The antiapoptotic activity in a bovine liver catalase preparation is not catalase}

To verify that the protective effects of our catalase preparation were indeed attributable to catalase, we treated the preparation with irreversible inhibitors of catalase, aminotriazole (Margoliash et al., 1960) or phenylhydrazine (Ortiz de Montellano and Kerr, 1983), and inhibited the catalase activity, respectively, by 99 and $96 \%$ (Table 1)Table 1. Unexpectedly, the catalase-inactivated extracts remained protective (Table 1). Moreover, purer catalase preparations from bovine liver, other organs, or other species were not protective (data not shown). Altogether, our observations suggested that catalase itself was not responsible for the antiapoptotic activity observed. Hence, we initiated a program to purify and identify the factor responsible for this protective effect. Because N18 cells represent a self-replenishing supply of neuron-like cells, we used SV-induced apoptosis of N18 cells as the bioassay in the purification program. Of note, the crude catalase had an antiproliferative effect on N18 cells, and indeed, the antiproliferative and antiapoptotic activities were found to be inseparable throughout the purification process (F. Esch and R. Ratan, unpublished observations), suggesting that a single molecular species was responsible for both activities. 


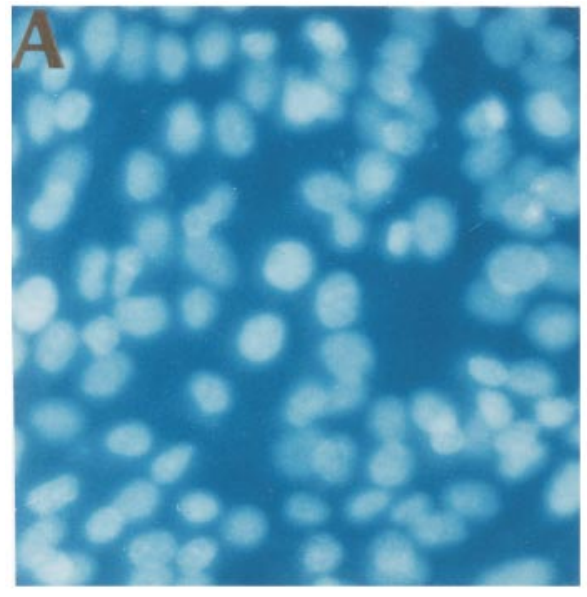

D S200-

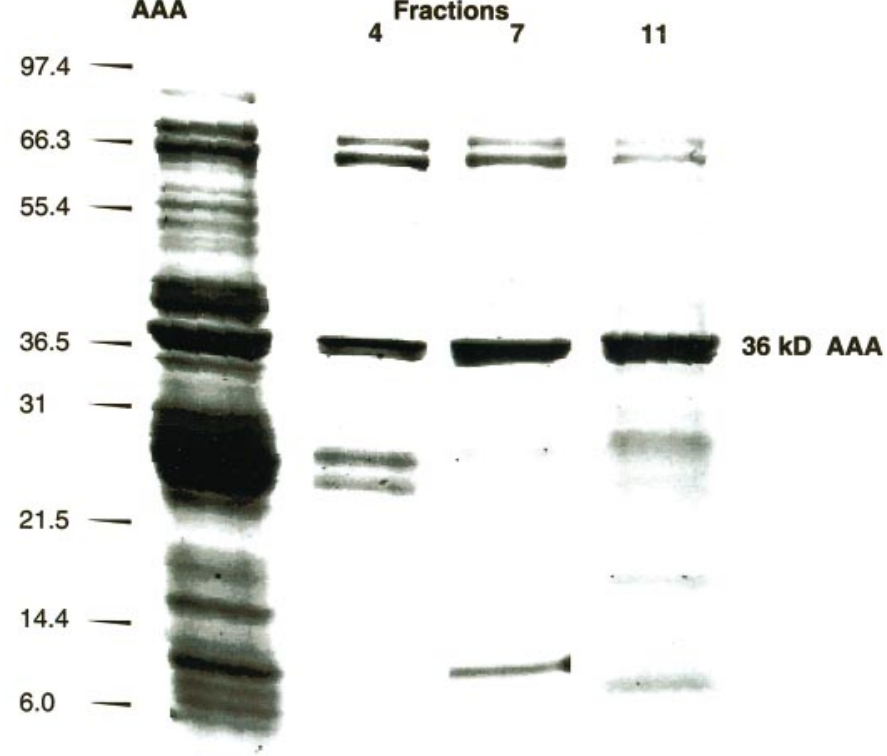

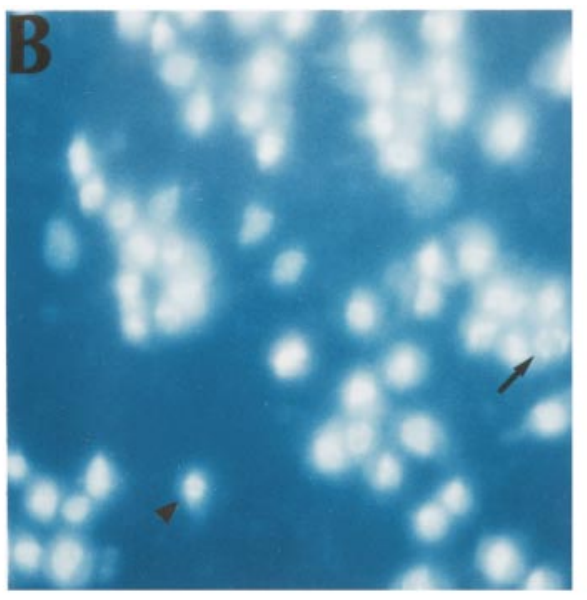

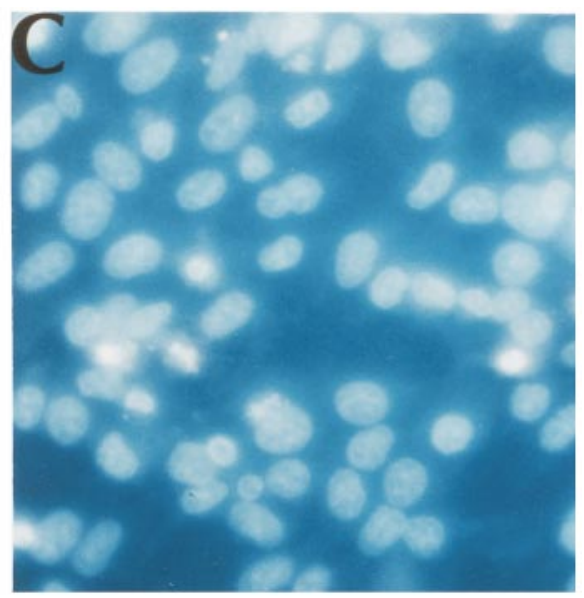

E

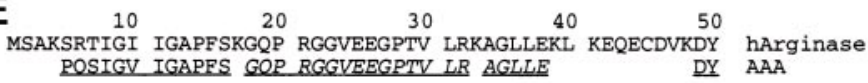
$\begin{array}{crrrrr}60 & 70 & 80 & 90 & 100 & \\ \text { GDLPFADIPN } & \text { DSPFQIVKNP } & \text { RSVGKASEQL } & \text { AGKVAQVKKN } & \text { GRISLVLGGD } & \text { hArginase } \\ \text { GDLSFADNLD } & \text { DSPFO } & \text { I ADVVAEV } & \text { AAA }\end{array}$ $\begin{array}{rrrrr}110 & 120 & 130 & 140 & 150 \\ \text { HSLAIGSISG HARVHPDLGV } & \text { IWVDAHTDIN } & \text { TPLTTTSGNL HGQPVSFLLK } & \text { hArginase } \\ & & \text { TGNL HGOPV } & \text { AAA }\end{array}$ $\begin{array}{rrrrrr}160 & 170 & 180 & 190 & 200 & \\ \text { ELKGKIPDVP } & \text { GFSWVTPCIS } & \text { AKDIVYIGLR } & \text { DVDPGEHYIL } & \text { KTLGIKYFSM } & \text { hArginase }\end{array}$ tPEVP GEYVVTPVI DIVXIGLR DVDPGEHY N YESM AAA

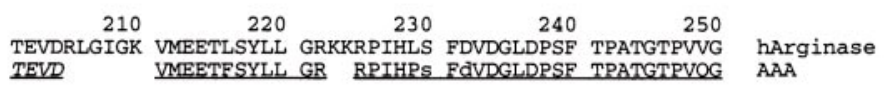
$\begin{array}{rrrrr}260 & 270 & 280 & 290 & 300 \\ \text { GLTYREGLYI } & \text { TEEIYKTGLL SGLDIMEVNP } & \text { SLGKTPEEVT RTVNTAVAIT } & \text { hArginase }\end{array}$ GLTYREGLYI TEEI TGLL SGLDIMEVNP SLG TPEEVT RTVVTTVAIT AAA

$\begin{array}{ll}310 & 320 \\ \text { LACFGLAREG NHKPIDYLNP PK } & \text { hArginase } \\ \text { MAXFGVAREG NH PIDYL } & \text { AAA }\end{array}$

Figure 2. Purification of an antiapoptotic activity in crude bovine liver catalase and its identification as arginase. $A-C$, Staining with the nucleic acid stain Hoechst 33258 demonstrates that the catalase-deficient extract (S200-AAA) inhibits SV-induced apoptosis in N18 mouse neuroblastoma cells Forty-eight hours after infection, cultured cells were stained with Hoechst 33258 at a concentration of $1 \mu \mathrm{g} / \mathrm{ml}$ for $30 \mathrm{~min}$ at $37^{\circ} \mathrm{C}$. $A$, Mock-infected N18 cells stained with Hoechst 33258 and visualized under fluorescence microscopy. $B$, SV-infected N18 cells 48 hr after the onset of infection stained and visualized as in $A$. The arrow points to a cell with radially organized hypercondensed chromatin, characteristic of a cell undergoing early apoptosis with chromatin condensed at the nuclear envelope. The arrowhead points to a cell with hypercondensed, fragmented chromatin characteristic of apoptosis. $C$, SV-infected N18 cells exposed to catalase-deficient S200-AAA $(135 \mu \mathrm{g} / \mathrm{ml})$ stained and visualized as in $A$. Note that the normal nuclear morphology seen in $A$ is preserved in the majority of cells. $D$, A 4-20\% SDS-PAGE analysis of bioactive S200-AAA loaded onto a pH 5.6-6.6 Immobiline IEF gel as described in Materials and Methods and the resulting IEF-AAA fractions (4, 7, 11 indicate the fraction numbers) stained with colloidal Coomassie brilliant blue. $E$, Human arginase I and lysylendopeptidase $\mathrm{c}$ fragments of bovine liver AAA. The complete 322 amino acid sequence of human arginase I (hArginase) is shown in the upper line. Amino acid sequences obtained from the bovine liver AAA/lysylendopeptidase c digestion fragments $(A A A)$ are underlined and shown below the human arginase sequence. Tentative sequence identifications are indicated by lowercase letters. Italicized sequences were identified using digests from two different IEF fractions. Two hundred six of 322 amino acids of bovine liver arginase were sequenced, comprising $64 \%$ of the entire sequence.

\section{Purification of an antiapoptotic activity from a bovine liver catalase preparation}

SDS-PAGE analysis of the crude commercial bovine liver catalase preparation indicated that up to $70 \%$ of the protein content could be accounted for by catalase itself. The AAA in the crude catalase extract was not retained by zinc-chelating Sepharose chromatography, whereas catalase was completely adsorbed by the matrix (data not shown). These results confirmed that the antiapoptotic activity was not catalase.
Subsequent anion exchange and size exclusion chromatography on Bioscale Q20 and Superdex 200 columns, respectively, further enhanced the purity of the antiapoptotic activity (Fig. $2 A-C$ ), resulting in recovery of $9 \mathrm{mg}$ of protein from $1 \mathrm{gm}$ of starting material. Purification to homogeneity was achieved in two electrophoretic steps involving isoelectric focusing and SDS-PAGE. IEF in $\mathrm{pH}$ 5.6-6.6 Immobiline gradient polyacrylamide gels under denaturing conditions greatly resolved the complex mixture obtained from size exclusion chromatography. Analytical 
A

$1 \mathrm{ug} \quad 2 \mathrm{ug}$

5 ug

B

66.3

55.4

36.5

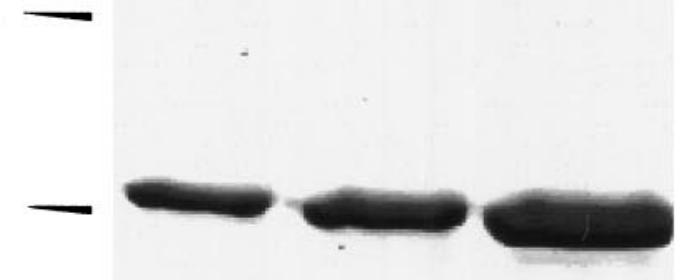

31.0

21.5
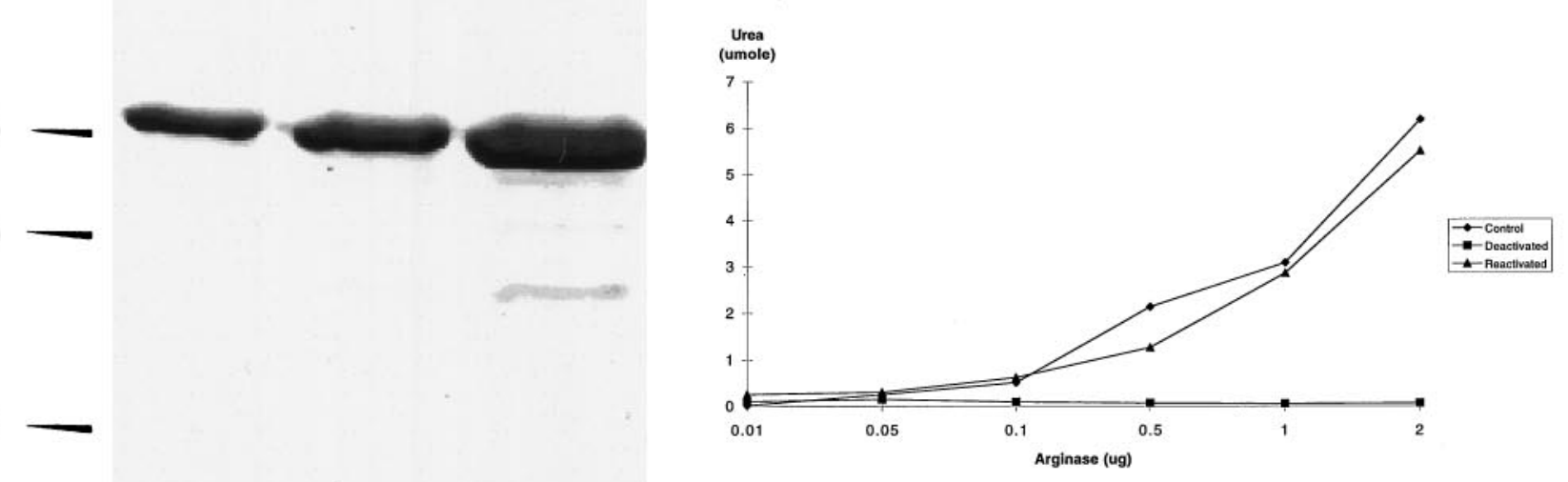

14.4

6.0

C

\section{D}
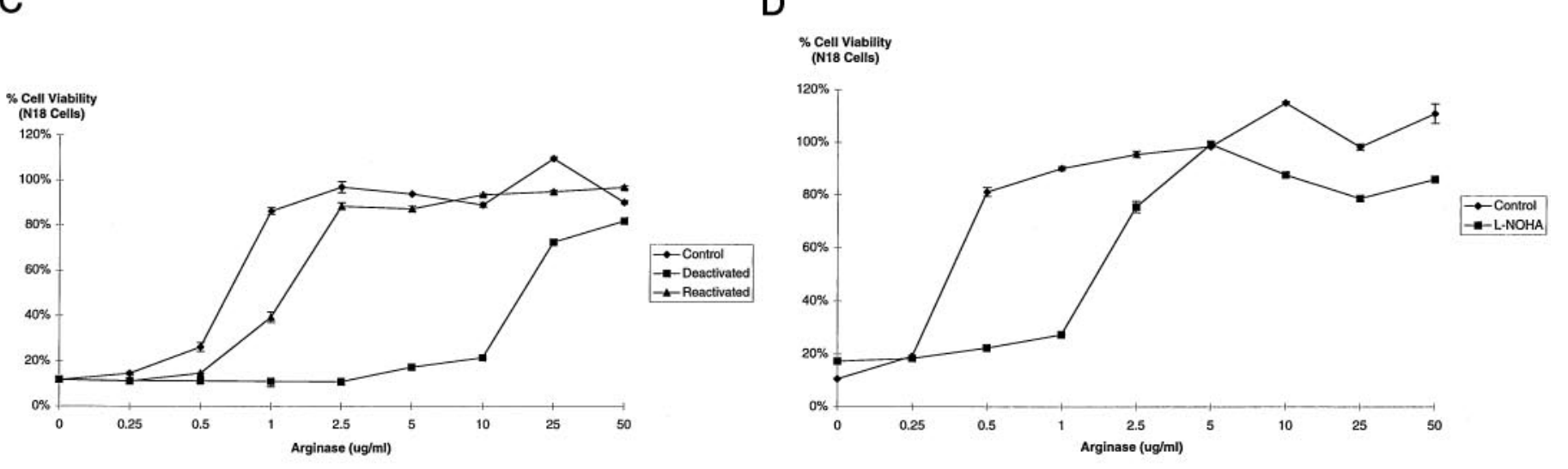

E \% Cell Viability
(N18 Cells)

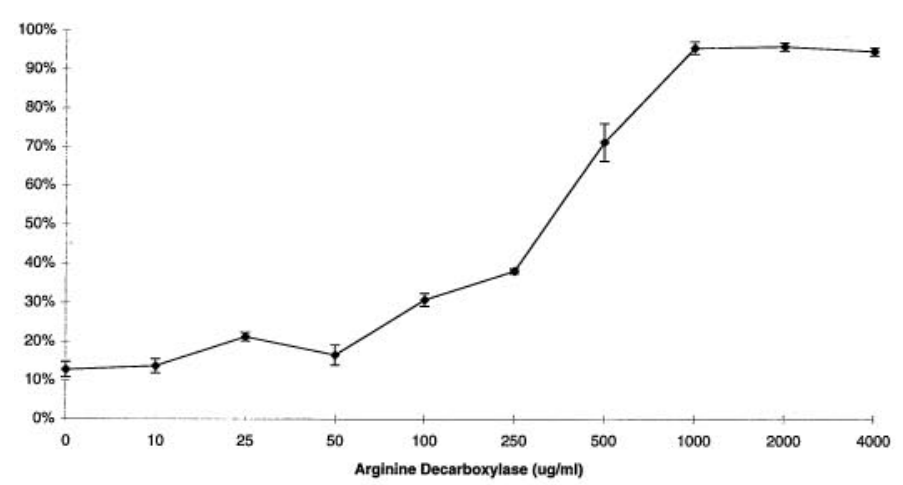


SDS-PAGE analyses showed that a $36 \mathrm{kDa}$ protein was enriched in three bioactive IEF fractions (Fig. 2D). Aliquots of these bioactive fractions were purified by SDS-PAGE on a $10 \%$ acrylamide gel, electroblotted onto PVDF, and stained with amido black. Direct N-terminal sequence analysis of the $36 \mathrm{kDa}$ protein failed, suggesting that the protein was N-terminally blocked. Thus, two of these $36 \mathrm{kDa}$ protein bands were excised from the electroblot and digested with lysylendopeptidase $\mathrm{c}$, and the digestion fragments were purified by reverse-phase liquid chromatography (RPLC). The RPLC peptide maps of the two digests were essentially superimposable, suggesting that similar if not identical proteins had been digested. Polypeptide microsequencing of all peptide peaks from one digest generated 206 amino acids of sequence data that showed high homology with the sequence of human liver arginase (Fig. $2 E$ ). Three peptide fragments from another digest were also sequenced and shown to contain arginase-related peptides. Virtually all experimentally derived peptide sequence data could be attributed to arginase, suggesting that the purified protein was homogeneous.

\section{An antiapoptotic activity in a bovine liver catalase preparation is attributable to arginase}

Arginase hydrolyzes arginine to urea and ornithine and has a manganese cofactor requirement. EDTA, a compound capable of chelating manganese, deactivates arginase during incubations at acidic $\mathrm{pH}$ values ( $\mathrm{pH}$ 5.5), but full enzymatic activity can be restored by subsequent treatment with manganese chloride $\left(\mathrm{MnCl}_{2}\right)$ (Kuhn et al., 1995). Using a $>97 \%$ pure preparation of recombinant rat liver arginase (Fig. $3 A$ ), we found that arginase enzymatic (Fig. 3B) and antiapoptotic activities (Fig. 3C) were dramatically decreased on exposure to EDTA and primarily restored with $\mathrm{MnCl}_{2}$. Moreover, the competitive inhibitor of arginase $N^{\omega}$-hydroxyl-L-arginine (L-NOHA; $100 \mu \mathrm{M}$ ) (Daghigh et al., 1994) decreased the survival responses of recombinant arginase by approximately fivefold in response to Sindbis virus infection in N18 cells (Fig. 3D). Altogether, these results suggest that arginase itself is responsible for the antiapoptotic activity and not some contaminant in the recombinant preparation.

Because arginase converts arginine to ornithine and urea, we next wanted to know whether the protective effects of arginase were because of depletion of arginine or an increase in ornithine and urea. To address this question, we used arginine decarboxylase, an enzyme that degrades arginine by cleaving its carboxyl group (Li et al., 1995) rather than its guanidino group (as arginase does). Arginine decarboxylase prevented SV-induced death in N18 cells (Fig. $3 E$ ), suggesting that it is depletion of arginine and not the generation of ornithine or urea that accounts for the protective effects of arginase. In support of this notion, we found no protective effect of ornithine $(10 \mu \mathrm{M}-1 \mathrm{mM})$ or urea $(10 \mu \mathrm{M}-1$ $\mathrm{mm}$ ) added separately or in combination to the bathing medium of N18 cells induced to die by SV infection (data not shown).

\section{\% Cell Viability (Cortical Neurons)}

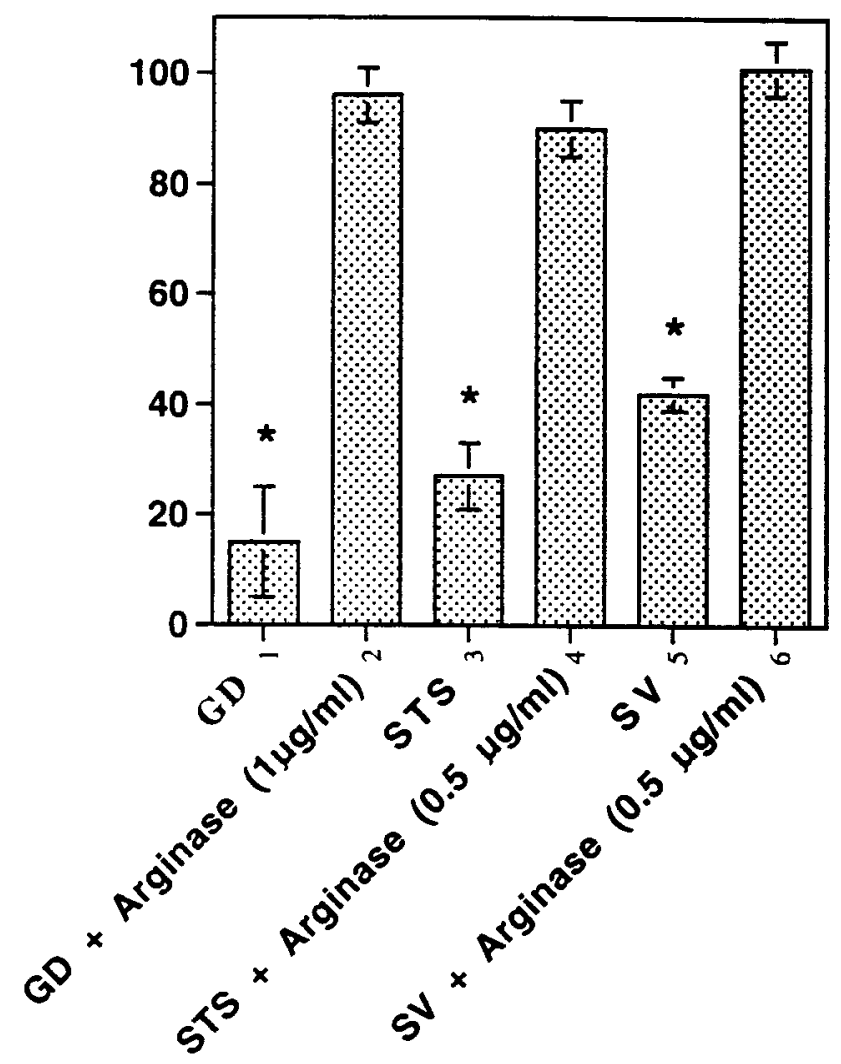

Figure 4. Recombinant rat liver arginase is a multipotent inhibitor of cell death in embryonic cortical neurons. At $24-72 \mathrm{hr}$ after plating, cultures were exposed to $1 \mathrm{~mm}$ HCA to inhibit competitively neuronal cystine transport and induce $G D$, exposed to $100 \mathrm{~nm} S T S$, or infected with $S V$ (MOI, 1-5). In parallel, exposure to each of these cytotoxic agents was conducted in the presence of recombinant arginase at $1 \mu \mathrm{g} / \mathrm{ml}(G D)$ or 0.5 $\mu \mathrm{g} / \mathrm{ml}(S T S$ and $S V)$. Recombinant arginase was added to the bathing medium at the same time that cytotoxic agents were added. The cells were harvested at $24 \mathrm{hr}(G D), 60 \mathrm{hr}(S T S)$, or $48 \mathrm{hr}(S V)$ and processed for LDH activity as described in Materials and Methods. Data (bars) are mean \pm SEM values from three to five experiments performed in triplicate wells; ${ }^{*} p<0.05$ by ANOVA.

\section{Arginase is protective in multiple neuronal apoptosis paradigms}

To investigate whether, like the crude commercial catalase, recombinant arginase is a multipotent inhibitor of neuronal apoptosis, we evaluated the effects of recombinant arginase added to the bathing medium of cortical neurons induced to undergo apoptosis by glutathione depletion-induced oxidative stress, by exposure to $100 \mathrm{nM}$ staurosporine, or by infection with Sindbis virus. In each of these paradigms, arginase was protective (Fig. 4).

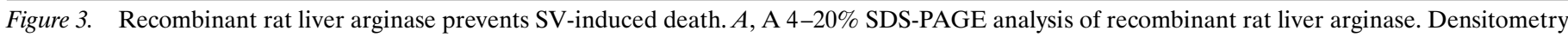

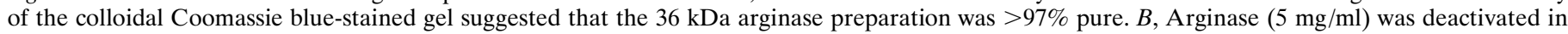

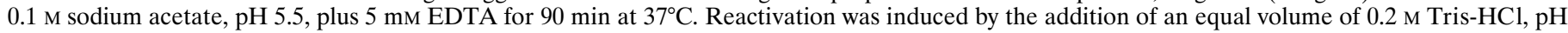

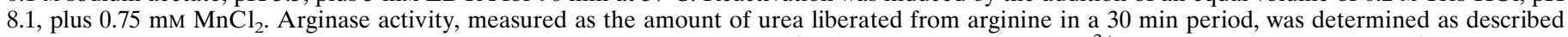

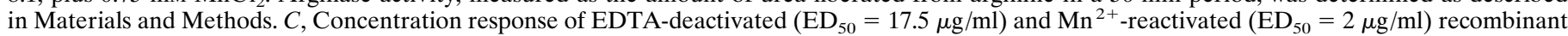

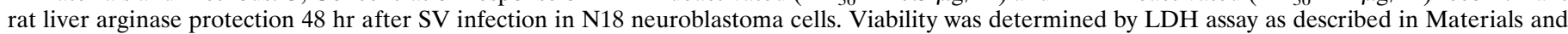

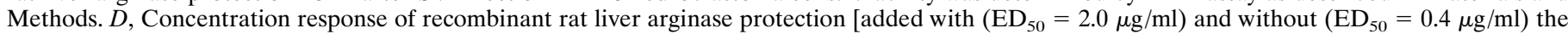

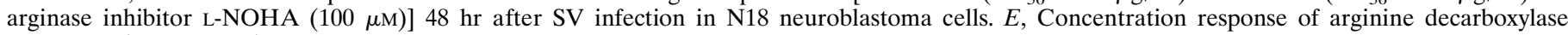
protection (1.0 units/mg) $48 \mathrm{hr}$ after SV infection in N18 neuroblastoma cells. 

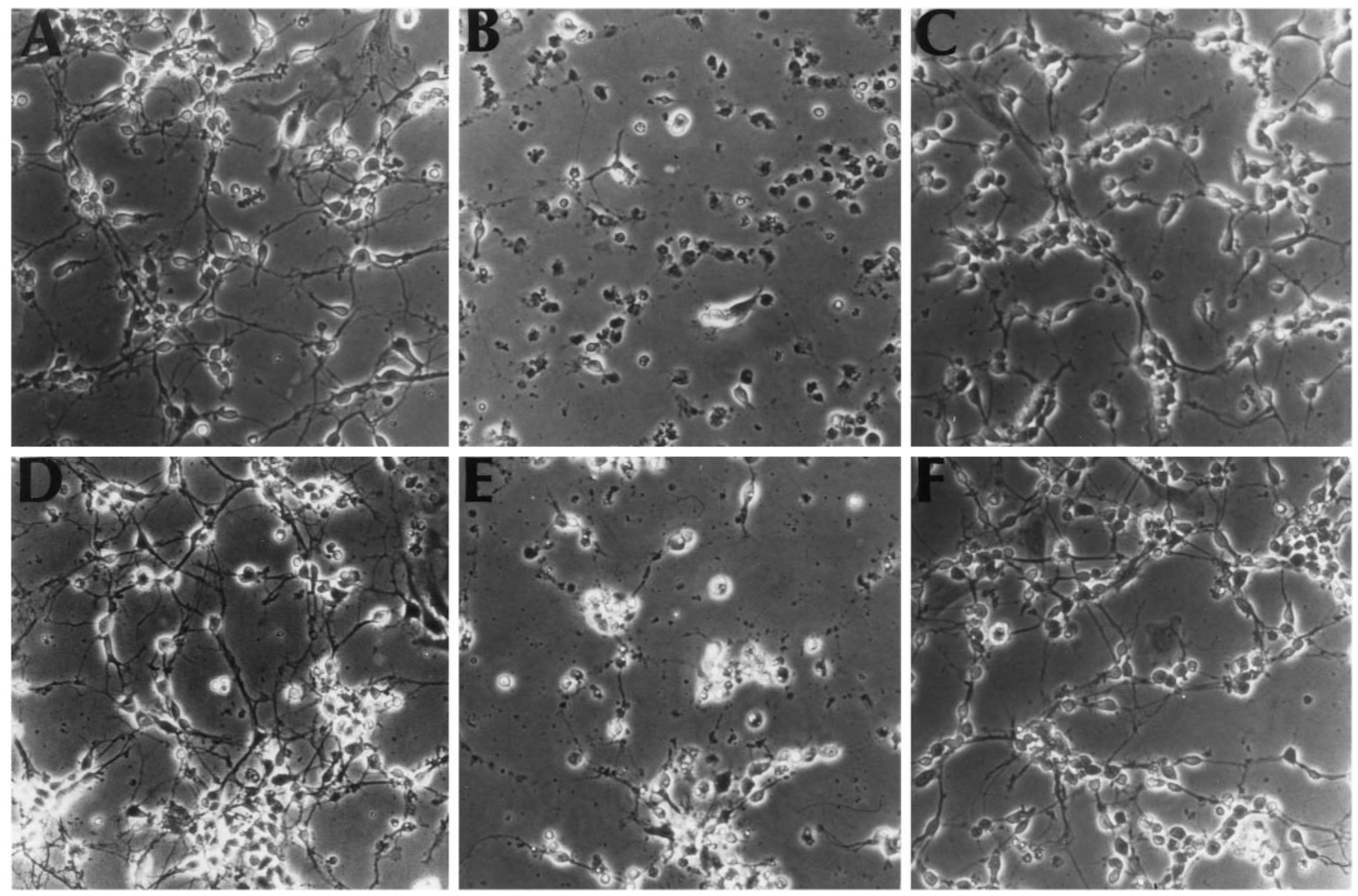

Figure 5. Phase contrast micrographs of cultured primary cortical neurons. $A$, Control [2 d in vitro (DIV)]. $B$, Twenty-four hours after 1 mm HCA exposure to induce GD (2 DIV). C, One millimolar HCA plus recombinant rat arginase at $1 \mu \mathrm{g} / \mathrm{ml}(2 \mathrm{DIV})$. $D$, Mock-infected control (3 DIV). $E$, Forty-eight hours after SV infection $(\mathrm{MOI}=5 ; 3 \mathrm{DIV}) . F, \mathrm{SV}$ infection plus recombinant rat arginase at $0.5 \mu \mathrm{g} / \mathrm{ml}$. Magnification, 200×.

Neurons exposed to these apoptotic stimuli revealed dramatic preservation of cell body and neurite morphology in the presence of arginase as monitored by phase contrast microscopy (Fig. 5; staurosporine data not shown).

\section{Arginase can act as a nitric oxide-independent inhibitor of apoptosis}

Because previous evidence has established that arginase can prevent excitotoxic necrosis in cortical cultures by inhibiting nitric oxide generation (Dawson et al., 1991), we considered the possibility that arginase was acting to prevent apoptosis by a similar mechanism. Pre- or cotreatment of N18 neuroblastoma cells with the general nitric oxide synthase inhibitor L-NMA $(100 \mu \mathrm{M})$ (Dawson et al., 1991; Schmidt et al., 1994) or the inducible nitric oxide synthesis inhibitor GED $(100 \mu \mathrm{M})$ had no effect on SVinduced cytotoxicity (Fig. 6A). Additionally, treatment of cortical neurons with the general nitric oxide synthase inhibitor L-NAME (100-500 $\mu \mathrm{M})$ did not influence cell death induced by glutathione depletion (Fig. 6B) or low doses of staurosporine (data not shown). Moreover, in each of these paradigms, nitric oxide synthase inhibitors were not toxic to control cultures. These results, along with previous observations that the inhibitors of nitric oxide synthase used herein do not significantly inhibit arginase activity (Fig. 6A) [also for review, see Morris (1998)], suggest that arginase can prevent apoptosis independent of nitric oxide synthase inhibition.
In considering other possible mechanisms of protection mediated by arginase, we noted that in addition to being a precursor for nitric oxide synthesis, arginine is also used for protein synthesis. Indeed, small molecule inhibitors of protein synthesis have been shown to abrogate neuronal apoptotic death in response to a host of stimuli (Martin et al., 1988; Ratan et al., 1994a,b; Serghini et al., 1994; Dreyer et al., 1995; Koh et al., 1995). To determine whether arginase-induced arginine depletion leads to suppression of protein synthesis, we measured the incorporation of radioactive cysteine and methionine into the perchloric acid (PCA)-precipitable (protein) fractions. Treatment of N18 neuroblastoma cells with arginase for $8 \mathrm{hr}$ reduced incorporation of methionine/cysteine into protein in a concentration-dependent manner. Moreover, the degree of protein synthesis inhibition is directly correlated with enhanced survival (Fig. 7A).

If arginase-induced arginine depletion leads to suppression of protein synthesis and enhanced cell survival, then depletion of other amino acids required for protein synthesis should also be protective. Asparaginase degrades asparagine to aspartate and ammonia. To determine whether depletion of asparagine, like arginine, prevents neuronal apoptosis, we treated SV-infected N18 neuroblastoma cells with a polyethylene glycol (PEG)conjugated form of the enzyme (PEG-asparaginase). PEGasparaginase (5 units/ml) diminished SV-induced death in N18 cells, whereas PEG-catalase (1-5000 units/ml) and PEG-super- 
A

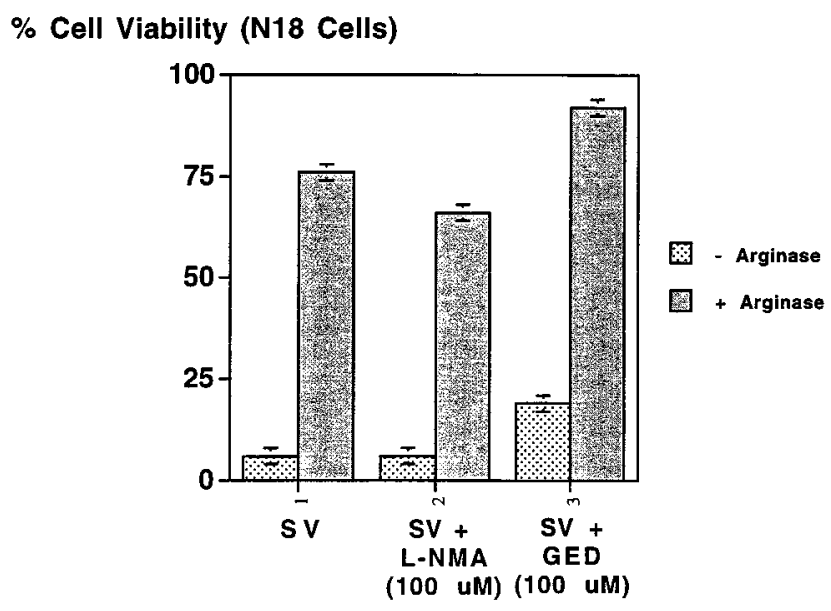

B

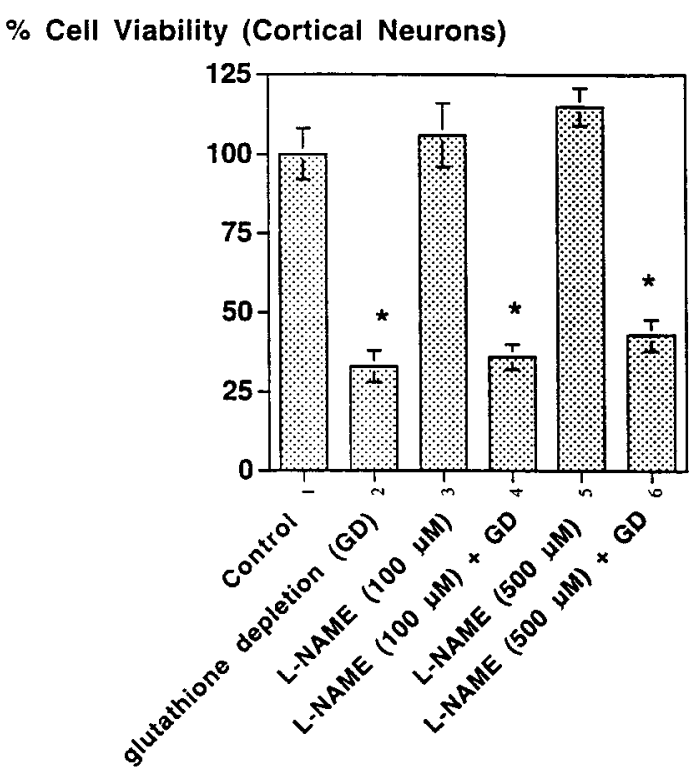

Figure 6. Protection by arginase is not mimicked by inhibitors of nitric oxide synthesis. $A$, The nitric oxide synthase inhibitors $L-N M A(100 \mu \mathrm{M})$ or $G E D(100 \mu \mathrm{M})$ do not significantly attenuate $S V$-induced cytotoxicity (assessed $48 \mathrm{hr}$ after infection) in N18 cells, nor do they inhibit the protective effects of recombinant arginase $(2.5 \mu \mathrm{g} / \mathrm{ml})$. Each bar represents the mean $\pm \mathrm{SD}$ for three to five experiments performed in triplicate. $B$, The nitric oxide synthase inhibitor $L-N A M E(100$ or $500 \mu \mathrm{M})$ does not significantly attenuate glutathione depletion-induced death in embryonic cortical neurons. Each bar represents the mean \pm SEM for three to five experiments performed in triplicate. An asterisk denotes a statistical difference from control ( $p<0.05$ by ANOVA).

oxide dismutase (PEG-SOD; 1-5000 units/ml) had no effect (Fig. 7B).

To verify that inhibition of protein synthesis is a mechanism by which arginase can prevent neuronal apoptosis, we examined the effects of arginase in an apoptosis paradigm in which the inhibition of protein synthesis potentiates cell death: TNF- $\alpha(10 \mathrm{ng} / \mathrm{ml})$ treatment of 3T3 mouse embryo fibroblasts (Beg and Baltimore, 1996). Consistent with the ability of arginase to suppress protein synthesis, arginase $(1-5 \mu \mathrm{g} / \mathrm{ml})$ potentiated TNF- $\alpha$-induced apoptosis (data not shown).

Taken together, our observations are consistent with the notion that arginase depletes arginine, leading to inhibition of protein synthesis and enhanced survival in neurons exposed to a host of apoptotic stimuli (Fig. 8).

\section{DISCUSSION}

A multipotent antiapoptotic activity in a bovine liver catalase preparation is arginase not catalase

We report the purification of a multipotent neuronal antideath activity from a commercial bovine liver "catalase" preparation and its identification as the urea cycle and nitric oxide synthaseregulating enzyme arginase.

Although extracellular catalase has been shown to abrogate serum deprivation-induced apoptosis in a human $\mathrm{T}$ cell line (Sandstrom and Buttke, 1993) and to support survival of cultured CNS neurons (Walicke et al., 1986), several observations herein argue that the protective factor in our extracellularly applied catalase preparation is not catalase. First, inhibition of catalase activity in the extract by $>95 \%$ using pharmacological inhibitors does not abrogate the protective effects of the preparation (Table 1). Second, purer preparations of catalase from a variety of sources do not inhibit oxidative stress-induced death in cortical neurons or Sindbis virus-induced death in cortical neurons or N18 neuroblastoma cells (data not shown). Third, adsorption of catalase from our catalase preparation onto a zinc-chelating Sepharose column removes catalase from the preparation but does not remove its antiapoptotic activity (Fig. $2 A-C$ ). Although these results seem to exclude extracellular catalase as a regulator of some types of neuronal apoptosis, they do not exclude the possibility that intracellular catalase or other intracellular peroxide scavengers such as glutathione peroxidase or pyruvate may be neuroprotective (Behl et al., 1994). Additionally, we found that extracellular catalase, but not arginase, could abrogate cytotoxicity of N18 cells induced by $2 \mathrm{~mm}$ peroxide (data not shown).

Because we had excluded catalase as the active agent in our antiapoptotic preparation, a purification program was initiated, and after the final isoelectric focusing step, a $36 \mathrm{kDa}$ protein was found to be enriched in three bioactive fractions (Fig. 2D). This $36 \mathrm{kDa}$ protein was microsequenced and identified as arginase (Fig. 2E). Indeed, the ability of recombinant arginase to abrogate neuronal apoptosis in response to glutathione depletion and oxidative stress, low doses of staurosporine, or Sindbis virus infection is consistent with the notion that this is the relevant biological activity in our crude catalase preparation (Figs. 3-5).

\section{Arginase-induced arginine depletion is neuroprotective}

Arginase is an abundant liver enzyme that hydrolyzes arginine into ornithine and urea. The ability of arginine decarboxylase, which decarboxylates arginine to form agmatine and $\mathrm{CO}_{2}(\mathrm{Li}$ et al., 1995), to mimic the protective effects of arginase (Fig. 3E) suggests that arginine depletion rather than generation of urea and ornithine accounts for the antiapoptotic effects of arginase. Of note, removal of arginine from the extracellular medium was not protective (data not shown), suggesting that an extracellular enzymatic sink is required to deplete intracellular arginine pools.

\section{Arginase can act as a nitric oxide-independent inhibitor of neuronal apoptosis}

By what mechanism(s) does arginase prevent neuronal apoptosis? Dawson and coworkers have established that extracellular arginase can abrogate excitotoxic necrosis in cortical neuronal cultures by inhibiting neuronal nitric oxide generation (Dawson et al., 1991). In this paradigm, arginase depletes arginine and pre- 


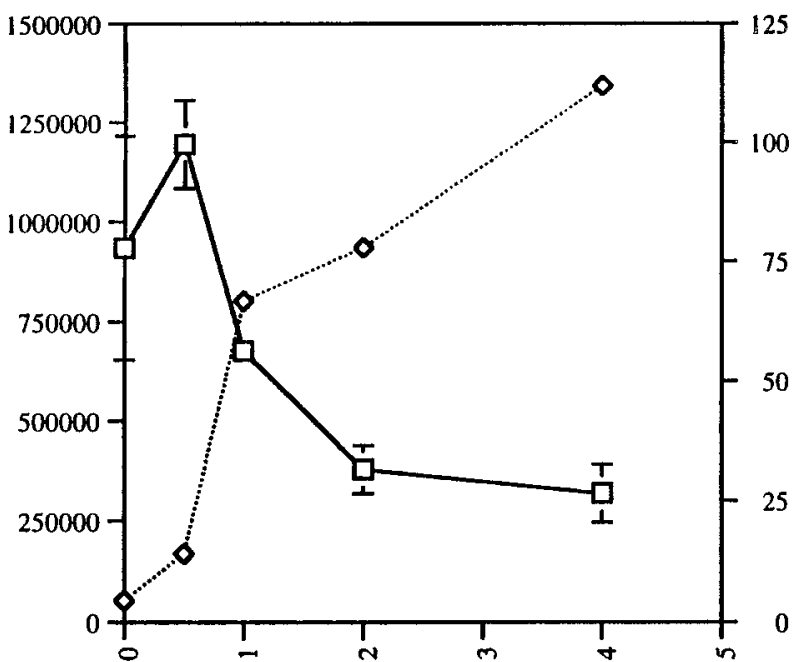

Arginase (ng/ml $\times$ 1000)

B

\section{$\%$ Cell Viability (N18 Cells)}

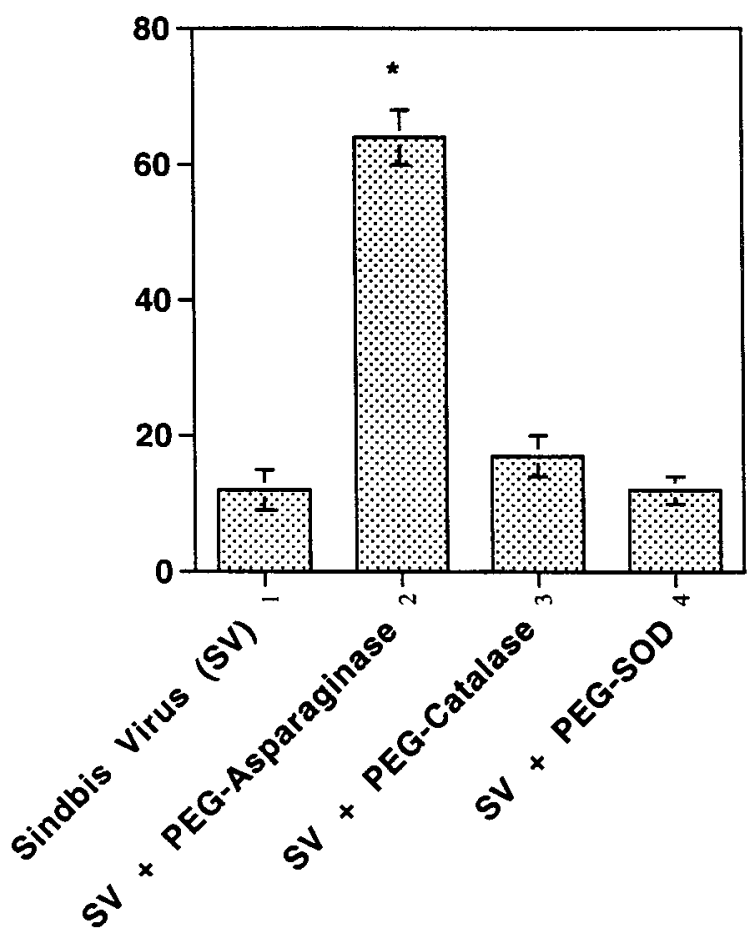

vents it from being oxidized by nitric oxide synthase to nitric oxide and citrulline. Furthermore, previous studies by Nicotera, Lipton, and colleagues have established that addition of nitric oxide to primary neurons is sufficient to induce apoptosis or necrosis depending on the concentration of nitric oxide donor used (Bonfoco et al., 1995). These findings, in conjunction with recent observations that arginase and inducible nitric oxide synthase are coordinately regulated in a number of cell types, including macrophages (Sonoki et al., 1997), are consistent with the notion that extracellular arginase may prevent neuronal apoptosis

\section{- S35 methionine/cysyeine incorporation/mg of protein …............ \% Viability}

Figure 7. Protection by arginase correlates with its ability to inhibit protein synthesis. $A$, Arginase decreases acid-precipitable $\left[{ }^{35}\right.$ S $]$ cysteine/methionine in N18 neuroblastoma cells in a concentration-dependent manner. Cultures were exposed to varying concentrations of arginase for $4 \mathrm{hr}$ at $37^{\circ} \mathrm{C}$. They were then labeled with $\left[{ }^{35} \mathrm{~S}\right]$ cysteine/methionine for $4 \mathrm{hr}$ as described in Materials and Methods. The labeling was stopped by three rapid cold washes. The cells were resuspended in 3\% PCA and separated into acid-soluble and -precipitable fractions by centrifugation. Squares indicate incorporation of radiolabel into acidprecipitable fractions (protein) expressed as cpm of $\left[{ }^{35} \mathrm{~S}\right]$ cysteine/ methionine per milligram of protein per $4 \mathrm{hr}$ of labeling at varying concentrations of recombinant rat arginase. In parallel, percentage viability (diamonds) was measured $48 \mathrm{hr}$ after SV infection in N18 cells cotreated with varying concentrations of recombinant arginase. Actinomycin-D $(2 \mu \mathrm{g} / \mathrm{ml})$, an inhibitor of transcription, inhibits incorporation of radioactive amino acids into protein by $80 \%$ and prevents SV-induced apoptosis in N18 cells (data not shown). $B$, In addition to arginase, another amino acid-degrading enzyme, asparaginase, prevents $S V$-induced death in N18 neuroblastoma cells. PEG-conjugated asparaginase (5 units/ml, a more stable form of asparaginase) was added to the bathing medium of $\mathrm{N} 18$ cells at the time of $S V$ infection $(\mathrm{MOI}=$ 5 ), and viability was assessed as described in Materials and Methods after $48 \mathrm{hr}$. In parallel, N18 cells infected with $S V$ were similarly treated with $P E G$-catalase (2100 units $/ \mathrm{ml}$ ) and $P E G-$ $S O D$ (100 units/ml) as controls. Each bar represents the mean \pm SEM for three to five experiments performed in triplicate. An asterisk denotes a statistical difference from $S V$-infected N18 cells $(p<0.05)$.

by removing arginine for use in nitric oxide synthesis. However, we were unable to detect a pro- or antiapoptotic effect for a broad array of nitric oxide synthase inhibitors in cortical neurons or N18 cells (Fig. 6), suggesting that although arginase may regulate survival via its effects on nitric oxide generation in some systems, nitric oxide is not a mediator of apoptosis in the paradigms examined here.

Several observations suggest that the antiapoptotic effects of arginase in the present study can be attributed to amino acid depletion and consequent suppression of protein synthesis. First, 


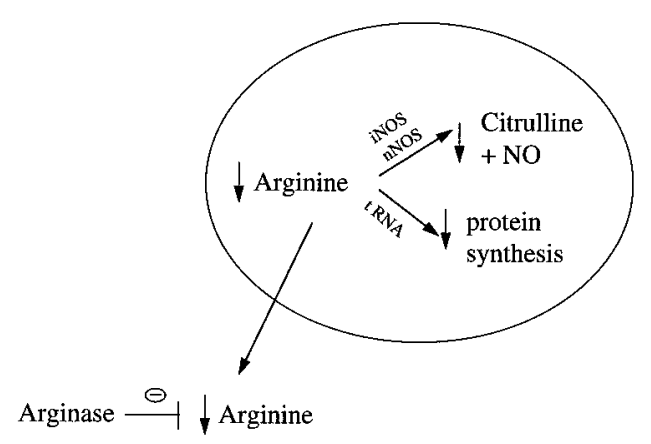

Figure 8. Diagram of proposed mechanisms by which extracellular arginine depletion (induced by arginase or arginine decarboxylase) can enhance cell survival. Extracellular arginase has been shown to inhibit nitric oxide generation and excitotoxic necrosis in mature primary cortical neurons exposed to glutamate (Dawson et al., 1991). We propose that extracellular arginase can inhibit cell death in neurons via an additional mechanism. Arginase depletes extracellular arginine, leading to intracellular arginine depletion. The intracellular arginine depletion results in an accumulation of uncharged tRNAs, leading to eIF- $2 \alpha$ phosphorylation and repression of global protein synthesis. Repression of protein synthesis can lead to suppression of apoptosis in response to some stimuli. $N O$, Nitric oxide; iNOS, inducible nitric oxide synthase; nNOS, neuronal nitric oxide synthase.

the ability of arginase to prevent Sindbis virus-induced death in N18 cells is directly proportional to its ability to inhibit the incorporation of radiolabeled amino acids into protein, a measure of protein synthesis (Fig. 7A). Second, another amino aciddepleting enzyme, asparaginase, which has been shown to suppress protein synthesis and proliferation in lymphocytes (Chuang et al., 1990), prevents SV-induced apoptosis in N18 cells (Fig. $7 B$ ). Third, arginase protects cortical neurons from glutathione depletion-induced or staurosporine-induced apoptosis, two paradigms in which inhibitors of macromolecular synthesis are known to be protective (Ratan et al., 1994b; Koh et al., 1995). Finally, arginase potentiates TNF-induced death of 3T3 mouse embryo fibroblasts, a type of apoptosis that is potentiated by inhibitors of macromolecular synthesis (Beg and Baltimore, 1996). Taken together, these observations define protein synthesis inhibition as a novel pathway by which arginine depletion can abrogate neuronal death (Fig. 8). Of course, the precise mechanism by which inhibition of protein synthesis leads to cell survival remains unclear, and several distinct schemes involving the inhibition of "killer" gene products (Martin et al., 1988) and the upregulation of antioxidant defenses (Ratan et al., 1994b; Furukawa et al., 1997) or antiapoptotic proteins (Furukawa et al., 1997) have been proposed.

\section{Arginase is an antiexcitotoxic and an antiapoptotic agent}

The ability of arginase to inhibit nitric oxide generation associated with excitotoxic necrosis (Dawson et al., 1991) and protein synthesis associated with apoptosis (Figs. 1, 4-7) suggests that arginine-depleting enzymes [infused directly into the CSF to avoid depletion of endothelial arginine (Huang et al., 1994; Samdani et al., 1997)] may be useful therapeutic agents in the treatment of acute neurological diseases such as stroke and spinal cord injury. In these disease states, nitric oxide-dependent cell death mediated by neuronal or inducible nitric oxide synthase is seen hours to days (Huang et al., 1994; Wu et al., 1994; Iadecola et al., 1995; Samdani et al., 1997) after the initial insult, and protein synthesis-dependent apoptosis is seen days to weeks after the onset of injury (Linnik et al., 1993; Bhat et al., 1996; Liu et al., 1997). That the antinecrotic and antiapoptotic effects of arginase may be therapeutically additive is supported by recent data from Choi and coworkers demonstrating that combined antiexcitotoxic and antiapoptotic measures are more effective in treating focal brain ischemia than either agent alone (Du et al., 1996a,b) (see Fig. 8).

\section{Arginase is expressed in the CNS}

The ability of extracellular bovine and rat liver arginase to regulate multiple pathways of neuronal death raises the possibility that arginase may be expressed in the CNS where it would be poised to function as a intracellular or extracellular regulator of cell survival and/or nitric oxide generation (Morris, 1998). Indeed, previous studies have established the presence of arginase activity, protein, and message in the CNS (Spector et al., 1985; Jenkinson et al., 1996). Fifty percent of the arginase activity in rat brain seems to be accounted for by the product of one gene (arginase I), the dominant gene product in bovine liver. The remaining $50 \%$ of brain arginase seems to be accounted for by a second, nonhepatic locus (arginase II) (Jenkinson et al., 1996; Morris et al., 1997). In addition to their distinct tissue distributions, arginase I and arginase II differ in several important aspects including immunological cross-reactivities, charge, and subcellular localization. For example, arginase I is primarily cytosolic, whereas arginase II is located within the mitochondrial matrix (Gotoh et al., 1996). Precisely how these enzymes differ in their biological function and regulation remains an area of active investigation.

With respect to regional localization in brain, immunocytochemical studies using an antibody to rat liver arginase (arginase I) indicate that not all CNS neurons contain arginase and that it is highly expressed under basal conditions in a number of brain regions, including the mitral cells and tufted cells of the olfactory bulb, the Purkinje cell somata of the cerebellum, and the facial motoneurons in the brainstem (Nakamura et al., 1990). Whether arginase also localizes to apoptosis-resistant (NADPH diaphorase/neuronal nitric oxide synthase) neurons in the cortex or striatum is unknown but is an intriguing possibility in light of our results demonstrating the antiapoptotic capacity of arginase.

In summary, we demonstrate that extracellularly applied arginase can inhibit neuronal apoptosis induced by multiple stimuli. Furthermore, we show that the protective effects of arginase in the paradigms examined here cannot be reproduced by an array of nitric oxide synthase inhibitors but rather seem to depend on depletion of arginine, resulting in protein synthesis inhibition. These studies identify amino acid depletion as a novel biological strategy to prevent pathological neuronal apoptosis and suggest that additional insight into the localization and regulation of arginase in the CNS will elucidate novel approaches to regulate cell death and nitric oxide synthesis in physiology and disease.

\section{REFERENCES}

Aruoma OI, Halliwell B, Hoey BM, Butler J (1989) The antioxidant $N$-acetylcysteine: its reaction with hydrogen peroxide, hydroxyl radical, superoxide and hypochlorous acid. Free Radic Biol Med 6:593-597.

Bae YS, Kang SW, Seo MS, Baines IC, Tekle E, Chock PB, Rhee SG (1997) Epidermal growth factor (EGF)-induced generation of hydrogen peroxide. J Biol Chem 272:217-221.

Beg AA, Baltimore D (1996) An essential role for NF-kappa B in preventing TNF-alpha-induced cell death. Science 274:782-784.

Behl C, Davis J, Lesley R, Schubert D (1994) Hydrogen peroxide mediates amyloid $\beta$ protein toxicity. Cell 77:817-827. 
Behrens MI, Koh J, Canzoniero LM, Sensi SL, Csernansky CA, Choi DW (1995) 3-Nitroproprionic acid induces apoptosis in cultured striatal and cortical neurons. NeuroReport 6:545-548.

Bhat RV, DiRocco R, Marcy VR, Flood DG, Zhu Y, Dobrzanski P, Siman R, Scott R, Contreras PC, Miller M (1996) Increased expression of IL-1 $\beta$ converting enzyme in hippocampus after ischemia: selective localization in microglia. J Neurosci 16:4146-4154.

Bonfoco E, Krainc D, Ankarcrona M, Nicotera P, Lipton SA (1995) Apoptosis and necrosis: two distinct events induced, respectively, by mild and intense insults with $N$-methyl-D-aspartate or nitric oxide/ superoxide in cortical cell cultures. Proc Natl Acad Sci USA 92:7162-7166.

Brannan TS, Maker HS, Raes IP (1980) Regional distribution of catalase in the adult rat brain. J Neurochem 36:307-309.

Bredesen DE (1995) Neural apoptosis. Ann Neurol 38:839-851.

Casciola-Rosen LA, Nicholson DW, Chong T, Rowan KR, Thornberry NA, Miller DK, Rosen A (1996) Apopain/CPP32 cleaves proteins that are essential for cellular repair: a fundamental principal of apoptotic death. J Exp Med 183:1957-1964.

Cavalli RC, Burke CJ, Kawamoto S, Soprano DR, Ash DE (1994) Mutagenesis of rat liver arginase expressed in Escherichia coli: role of conserved histidines. Biochemistry 33:10652-10657.

Chuang JC, Yu CL, Wang SR (1990) Modulation of lymphocyte proliferation by enzymes that degrade amino acids. Clin Exp Immunol $82: 469-472$.

Clarke AR, Maandag ER, van Roon M, van der Lught NM, vander Valk M, Hooper ML, Berns A, te Riele H (1992) Requirement for a functional Rb-1 gene in murine development. Nature 359:328-330.

Clarke PGH (1994) Neuronal death in development of the vertebrate nervous system. Semin Neurosci 6:291-297.

Clemens JA, Stephenson DT, Smalstig EB, Dixon EP, Little SP (1997) Global ischemia activates nuclear factor-kappa B in forebrain neurons of rats. Stroke 28:1073-1080.

Cotman CW, Anderson AJ (1995) A potential role for apoptosis in neurodegeneration and Alzheimer's disease. Mol Neurobiol 10:19-45.

Crowe MJ, Bresnahan JC, Shuman SL, Masters JN, Beattie MS (1997) Apoptosis and delayed degeneration after spinal cord injury in rats and monkeys. Nat Med [Erratum (1997) 3:240] 3:73-76.

Daghigh F, Fukuto JM, Ash DE (1994) Inhibition of rat liver arginase by an intermediate in NO biosynthesis, $N^{\mathrm{G}}$-hydroxy-L-arginine: implications for the regulation of nitric oxide biosynthesis by arginase. Biochem Biophys Res Commun 202:174-180.

Dawson VL, Dawson TM, London ED, Bredt DS, Snyder SH (1991) Nitric oxide mediates glutamate neurotoxicity in primary cortical cultures. Proc Natl Acad Sci USA 88:6368-6371.

Dreyer EB, Zhang D, Lipton SA (1995) Transcriptional or translational initiation blocks low dose NMDA-mediated cell death. NeuroReport 6:942-944.

Du C, Hu R, Csernansky CA, Hsu CY, Choi DW (1996a) Very delayed infarction after focal cerebral ischemia: a role for apoptosis? J Cereb Blood Flow Metab 16:195-201.

Du C, Hu R, Csernansky CA, Hsu CY, Choi DW (1996b) Additive neuroprotective effects of dextrorphan and cycloheximide in rats subjected to transient focal cerebral ischemia. Brain Res 718:233-236.

Estus S, Zaks WJ, Freeman RS, Gruda M, Bravo R, Johnson Jr EM (1994) Altered gene expression in neurons during programmed cell death: identification of c-jun as necessary for neuronal apoptosis. J Cell Biol 127:1717-1727.

Ferrari G, Yan CYI, Greene LA (1995) N-Acetylcysteine (D- and L-stereoisomers) prevents apoptotic death in neuronal cells. J Neurosci 15:2857-2866.

Freeman RS, Estus S, Johnson Jr EM (1994) Analysis of cell cycle -related gene expression in post-mitotic neurons: selective induction of cyclin D1 during programmed neuronal death. Neuron 12:343-355.

Furukawa K, Estus S, Fu W, Mark RJ, Mattson MP (1997) Neuroprotective action of cycloheximide involves induction of Bcl-2 and antioxidant pathways. J Cell Biol 136:1137-1149.

Gagliardini V, Fernandez P, Lee RKK, Drexler HCA, Rotello RJ, Fishman MC, Yuan J (1994) Prevention of vertebrate neuronal death by the Crm A gene. Science 263:826-828.

Garcia I, Martinou I, Tsujimoto Y, Martinou J-C (1992) Prevention of programmed cell death of sympathetic neurons by the bcl-2 protooncogene. Science 258:302-304.

Gotoh T, Sonoki T, Nagasaki A, Terada K, Takiguchi M, Mori M (1996) Molecular cloning of cDNA for nonhepatic mitochondrial arginase (arginase II) and comparison of its induction with nitric oxide synthase in a murine macrophage-like cell line. FEBS Lett 395:119-122.

Greenlund LJS, Deckwerth TL, Johnson Jr EM (1995) Superoxide dismutase delays neuronal apoptosis: a role for reactive oxygen species in programmed neuronal death. Neuron 14:303-315.

Gwag BJ, Lobner D, Koh JY, Wie MB, Choi DW (1995) Blockade of glutamate receptors unmasks neuronal apoptosis after oxygen-glucose deprivation in vitro. Neuroscience 68:615-619.

Ham J, Babij C, Whitfield J, Pfarr CM, Lallemand D, Yaniv M, Rubin LL (1995) A c-Jun dominant negative mutant protects sympathetic neurons against programmed cell death. Neuron 14:927-939.

Hoyt KR, Gallagher AJ, Hastings TG, Reynolds IJ (1997) Characterization of hydrogen peroxide toxicity in cultured rat forebrain neurons. Neurochem Res 22:333-340.

Huang Z, Huang PL, Panhian N, Dalkara T, Fishman MC, Moskowitz MA (1994) Effects of cerebral ischemia in mice deficient in neuronal nitric oxide synthase. Science 265:1883-1885.

Iadecola C, Zhang F, Xu X (1995) Inhibition of inducible nitric oxide synthase ameliorates cerebral ischemic damage. Am J Physiol 268:R286-R292.

Jacks T, Fazeli A, Schmitt EM, Bronson RT, Goodell MA, Weinberg RA (1992) Effects of an Rb mutation in the mouse. Nature 359:295-300.

Jenkinson CP, Grody WW, Cedarbaum SD (1996) Comparative properties of arginase. Comp Biochem Physiol 114B:107-132.

Johnson EM, Gorin PM, Brandeis LD, Pearson J (1980) Dorsal root ganglion neurons are destroyed by exposure in utero to maternal antibody to nerve growth factor. Science 210:916-918.

Kingma JG, Simard D, Rouleau JR, Tanguay RM, Currie RW (1996) Effect of 3-aminotriazole on hyperthermia-mediated cardioprotection in rabbits. Am J Physiol 270:H1165-H1171.

Koh JY, Wie MB, Gwag BJ, Sensi SL, Canzoniero LMT, Demaro J, Csernansky C, Choi DW (1995) Staurosporine-induced neuronal apoptosis. Exp Neurol 135:153-159.

Kuhn NJ, Ward S, Piponski M, Young TW (1995) Purification of human hepatic arginase and its manganese (II)-dependent and $\mathrm{pH}$-dependent interconversion between active and inactive forms: a possible $\mathrm{pH}$ sensing function of the enzyme on the ornithine cycle. Arch Biochem Biophys 320:24-34.

Lee EY-HP, Chang C-Y, Hu N, Wang Y-CJ, Lai C-C, Herrup K, Lee W-H, Bradley A (1992) Mice deficient for Rb are nonviable and show defects in neurogenesis and haematopoiesis. Nature 359:288-294.

Levine B, Huang Q, Isaacs JT, Reed JC, Griffin DE, Hardwick JM (1993) Conversion of lytic to persistent alphavirus infection by the bcl-2 cellular oncogene. Nature 361:739-742.

Lewis J, Wesselingh SL, Griffin DE, Hardwick JM (1996) Alphavirusinduced apoptosis in mouse brains correlates with neurovirulence. J Virol 70:1828-1835.

Li G, Regunathan S, Reis DJ (1995) Agmatine is synthesized by a mitochondrial arginine decarboxylase in rat brain. Ann NY Acad Sci 763:325-329.

Lin K-I, Lee S-H, Narayanan R, Baraban JM, Hardwick JM, Ratan RR (1995) Thiol agents and bcl-2 identify an alphavirus-induced apoptotic pathway that requires activation of the transcription factor NF-kappa B. J Cell Biol 131:1149-1161.

Linnik MD, Zobrist RH, Hatfield MD (1993) Evidence supporting a role for programmed cell death in focal cerebral ischemia in rats. Stroke 24:2002-2009.

Liu XZ, Xu XM, Hu R, Du C, Zhang SX, McDonald JW, Dong HX, Wu YJ, Fan GS, Jacquin MF, Hsu CY, Choi DW (1997) Neuronal and glial apoptosis after traumatic spinal cord injury. J Neurosci 17:5395-5406.

Loo DT, Copani A, Pike CJ, Whittemore ER, Walencewicz AJ, Cotman CW (1993) Apoptosis is induced by $\beta$-amyloid in cultured central nervous system neurons. Proc Natl Acad Sci USA 90:7951-7955.

Mah SP, Zhong LT, Liu Y, Roghani A, Edwards RH, Bredesen DE (1993) The proto-oncogene bcl-2 inhibits apoptosis in PC-12 cells. J Neurochem 60:1183-1186.

Margoliash E, Novogrodsky A, Schejter A (1960) Irreversible reaction of 3-amino-1:2:4-triazole and related inhibitors with the protein of catalase. Biochem J 74:339-348.

Martin DP, Schmidt RE, DiStefano PS, Lowry OH, Carter JG, Johnson EM (1988) Inhibitors of protein synthesis and RNA synthesis prevent neuronal death caused by nerve growth factor deprivation. J Cell Biol 106:829-844.

Miller TM, Moulder KL, Knudson CM, Creedon DJ, Deshmukh M, 
Korsmeyer SJ, Johnson Jr EM (1997) Bax deletion further orders the cell death pathway in cerebellar granule cells and suggests a caspaseindependent pathway to cell death. J Cell Biol 139:205-217.

Morris SM (1998) Arginine synthesis, metabolism, and transport: regulators of nitric oxide synthesis. In: Cellular and molecular biology of nitric oxide (Laskin JD, Laskin DL, eds). Monticello, NY: Dekker, in press.

Morris SM, Bhamidipati D, Kepka-Lenhart D (1997) Human type II arginase: sequence analysis and tissue-specific gene expression. Gene 193:157-161.

Mu X, He J, Anderson DW, Trojanowski JQ, Springer JE (1996) Altered expression of bcl-2 and bax mRNA in amyotrophic lateral sclerosis spinal cord motor neurons. Ann Neurol 40:379-386.

Murphy TH, Schnaar RL, Coyle JT (1990) Immature cortical neurons are uniquely sensitive to glutamate toxicity by inhibition of cystine uptake. FASEB J 4:1624-1633.

Nakamura H, Saheki T, Nakagwa S (1990) Differential cellular localization of enzymes of L-arginine metabolism in rat brain. Brain Res 90:108-112.

Nicholson DW, Thornberry NA (1997) Caspases-killer proteases. Trends Biochem Sci 22:299-306.

Oh JH, O’Malley KL, Krajewski S, Reed JC, Oh YJ (1997) Bax accelerates staurosporine-induced but suppresses nigericin-induced neuronal cell death. NeuroReport 8:1851-1856.

Oppenheim RW (1991) Cell death during development of the nervous system. Annu Rev Neurosci 14:453-501.

Ortiz de Montellano PR, Kerr DE (1983) Inactivation of catalase by phenylhydrazine. J Biol Chem 258:10558-10563.

Pittman RN, Wang SW, DiBenedetto AJ, Mills JC (1993) A system for characterizing cellular and molecular events in programmed neuronal death. J Neurosci 13:3669-3680.

Portera-Calliau C, Hedreen JC, Price DL, Koliatosis VE (1995) Evidence for apoptotic cell death in Huntington's disease and excitotoxic animal models. J Neurosci 15:3775-3787.

Prehn JH, Jordan J, Ghadge GD, Preis E, Galindo MF, Roos RP, Krieglstein J, Miller RJ (1997) $\mathrm{Ca}^{2+}$ and reactive oxygen species in staurosporine-induced neuronal apoptosis. J Neurochem 68: $1679-1685$.

Ratan RR, Murphy TH, Baraban JM (1994a) Oxidative stress induces apoptosis in embryonic cortical neurons. J Neurochem 62:376-379.

Ratan RR, Murphy TH, Baraban JM (1994b) Macromolecular synthesis inhibitors prevent oxidative stress-induced apoptosis in embryonic cortical neurons by shunting cysteine from protein synthesis to glutathione. J Neurosci 14:4385-4392.

Rorth M, Jensen PK (1967) Determination of catalase activity by means of the Clark oxygen electrode. Biochim Biophys Acta 139:173-176.
Rothstein JD, Bristol LA, Hostler B, Brown RH, Kuncl RW (1994) Chronic inhibition of superoxide dismutase produces apoptotic death of spinal neurons. Proc Natl Acad Sci USA 91:4155-4159.

Samdani AF, Dawson TM, Dawson VL (1997) Nitric oxide synthase in models of focal ischemia. Stroke 28:1283-1288.

Sandstrom PA, Buttke TM (1993) Autocrine production of extracellular catalase prevents apoptosis of the human CEM T-cell line in serum free medium. Proc Natl Acad Sci USA 90:4708-4712.

Satoh T, Sakai N, Enokido Y, Uchiyama Y, Hatanaka H (1996) Free radical-independent protection by nerve growth factor and $\mathrm{Bcl}-2$ of PC12 cells from hydrogen peroxide triggered apoptosis. J Biochem (Tokyo) 120:540-546.

Schmidt K, Brunner F, Mayer B (1994) Inhibitors of brain nitric oxide synthase. Binding kinetics, metabolism, and enzyme inactivation. J Biol Chem 269:1674-1680.

Serghini R, Froissard P, Sola B, Duval D (1994) Cycloheximide and actinomycin-D block the toxic effect of glutamic acid on PC12 cells. NeuroReport 6:29-32.

Sonoki T, Nagasaki A, Gotoh T, Takiguchi M, Takeya M, Matsuzaki H, Mori M (1997) Coinduction of nitric-oxide synthase and arginase I in cultured rat peritoneal macrophages and rat tissues in vivo by lipopolysaccharide. J Biol Chem 272:3689-3693.

Spector EB, Kern RM, Haggerty DF, Cederbaum SD (1985) Differential expression of multiple forms of arginase in cultured cells. Mol Cell Biochem 66:45-53.

Tong L, Perez-Polo JR (1996) Effect of nerve growth factor on AP-1, NF-kappa B, and Oct-1 DNA binding activity in apoptotic PC12 cells: extrinsic and intrinsic elements. J Neurosci Res 45:1-12.

Troy CM, Shelanski ML (1994) Down-regulation of copper/zinc superoxide dismutase causes apoptotic death in PC12 neuronal cells. Proc Natl Acad Sci USA 91:6384-6387.

Walicke P, Varon S, Manthorpe M (1986) Purification of a human red blood cell protein supporting the survival of cultured CNS neurons, and its identification as catalase. J Neurosci 6:1114-1121.

Whittemore ER, Loo DT, Cotman CW (1994) Exposure to hydrogen peroxide induces cell death via apoptosis in cultured rat cortical neurons. NeuroReport 5:1485-1488.

Wood KA, Youle RJ (1995) The role of free radicals and p53 in neuron apoptosis in vivo. J Neurosci 15:5851-5857.

Wu W, Liuzzi FJ, Schinco FP, Depto AS, Li Y, Mong JA, Dawson TM, Snyder SH (1994) Neuronal nitric oxide synthase is induced in spinal neurons by traumatic injury. Neuroscience 61:719-726.

Wyllie AH, Kerr JFR, Currie AR (1980) Cell death: the significance of apoptosis. Int Rev Cytol 68:251-306. 